Article

\title{
Printed Paper Waste as an Alternative Growing Medium Component to Produce Brassica Seedlings under Nursery Conditions
}

\author{
Antonios Chrysargyris ${ }^{1}$, Panayiota Xylia ${ }^{1}$, Gorkem Akinci ${ }^{2}{ }^{\circledR}$, Konstantinos Moustakas ${ }^{3}{ }^{(1)}$ and \\ Nikolaos Tzortzakis $1, *$ (D) \\ 1 Department of Agricultural Sciences, Biotechnology and Food Science, Cyprus University of Technology, \\ Limassol 3603, Cyprus; a.chrysargyris@cut.ac.cy (A.C.); pa.xylia@edu.cut.ac.cy (P.X.) \\ 2 Department of Environmental Engineering, Dokuz Eylul University, 35280 Izmir, Turkey; \\ gorkem.akinci@deu.edu.tr \\ 3 School of Chemical Engineering, National Technical University of Athens, 15780 Athens, Greece; \\ konmoust@central.ntua.gr \\ * Correspondence: nikolaos.tzortzakis@cut.ac.cy; Tel.: +357-25002280
}

Received: 29 June 2020; Accepted: 17 July 2020; Published: 25 July 2020

\begin{abstract}
Significant quantities of paper waste (PW) have been accumulated in recent years and the reuse/recycling of PW is required due to environmental concerns. In the present study, printed $\mathrm{PW}$ was used as a peat $(\mathrm{P})$ substitute in growing medium for the Brassica seedlings production, considering recycling, sustainable agriculture, and partly peat replacement. Seeds of cauliflower, broccoli, and cabbage were seeded in growing media made of $0-10-30-50 \% \mathrm{PW}$. The addition of $\mathrm{PW}$ improved the growing media $\mathrm{pH}$ and mineral content, reduced the media aeration, and affected seed emergence. The PW decreased plant growth and the effects were more pronounced at $50 \%$ $\mathrm{PW}$. The $\mathrm{PW} \geq 30 \%$ decreased stomatal conductance, while chlorophyll fluorescence and content of chlorophylls decreased with high PW ratio, negatively affecting the plant physiology. The PW decreased plant sodium and iron and increased potassium, calcium, magnesium, and copper content. The PW increased antioxidant activity to a certain degree for cauliflower and cabbage and resulted in no change for broccoli, while polyphenols increased in cabbage seedlings. The addition of PW did not cause cellular damage as both lipid peroxidation and hydrogen peroxide production remained at low levels, maintaining low levels on the antioxidant enzymes (catalase, superoxide dismutase, peroxidase) metabolism. The present study shows that low PW content can partially replace peat for Brassica seedling production under a sustainable agriculture and environmentally friendly scheme.
\end{abstract}

Keywords: printed paper waste; peat; Brassica oleracea; antioxidant activity; enzymes; recycling; sustainable agriculture

\section{Introduction}

The industrial sector of pulp and paper is enormous with more than 0.3 billion tons of products and more than 0.5 billion dollars of global revenues on an annual basis [1]. Recently, the wastes derived from the paper mill industry are estimated to be $1 \%$ of the products (more than 3 million tons) annually, with $2.5 \%$ of increasing rates annually, which actually estimated an additional 2.5 million tons of solid waste to be managed until the first half of the 21st century [2]. The appropriate pulp and paper solid waste disposal and management is a severe global issue [3]. Several practices have been adapted for the pulp and paper waste management, including the production of recycled paper, the incineration for energy recovery, bioproduction of fumaric acid, and the direct land application for soil amendment [4,5]. Nonetheless, extracting the ink, clay, coatings, and chemicals from paper waste to manufacture paper 
reuse produces a vast quantity of de-inked paper sludges [6]. Other minor outlets are the use as animal bedding, recycling for the production of new waste-based material for building constructions [4], mortar production [7], green composites [8], cyanoethyl cellulose [9], and compost production [10,11]. Even with the suggested waste management application and the relevant literature, the pulp and paper industry continues to be unsuitable with inadequate comprehensive approaches. Waste management through the production of recycled paper can save fuel (up to 2.5 tons of oil) and water (up to 25 tons) [12]. Caputo and Pelagagge [13] presented a techno-economical study of a fluidized bed-based waste-to-energy sludge disposal plant for the paper industry with 15-20 million euro savings within 15 years of operation, as well as environmental benefits. Despite the increasing interest for the paper mill sludges composting and vermicomposting [14], the disposal of wastes on land is the most commonly and traditionally way of management. Both composting and land application (landfill or land spread) are expensive, and therefore, alternative practices of waste management need to be explored [13]. Successful applications of paper waste (PW) sludge to ceramic products have been reported by Vieira et al. [15]. According to Waste classification and the European List of Waste (2000/532/EC-01.06.2015), there are many types of waste generated by paper industry and only some can be used (recycled) in several sectors, including agriculture.

One well-functioning way to handle sustainably is paper waste composting, which is not just time-demanding and expensive, but also a fairly slow and space-demanding operation. Composting paper mill sludge and paper waste might result in the removal of material stability and odors, but often needs a nitrogen supplement due to its low nitrogen content and additional handlings (material processing, transport cost, storage infrastructures). In that sense, landfill or land spread disposition of paper mill sludges is commonly adapted as a routine method [4]. Agronomic application of paper waste is mainly targeted towards soil structure improvement rather than mineral enrichment. However, land spread is an effective way for soil utilization, as it restores nutrients and organic matter back to the soil, otherwise they would be lost. The utilization of paper mill sludge as soil conditioners generates interest to explore the material for its application as a substrate for crop production in the open field or protected cultivations, and replacing or decreasing dependence on substrates based on peat [16].

Ordinarily, peat is the main component in nurseries, but its existence is doubtful in the next years as a result of environmental restrictions $[16,17]$. Peat extraction commits environmental destruction of vulnerable ecosystems [18], greenhouse gases emission, carbon losses, and increased cost for transferring/storage [19]. Moreover, peatlands are under protection based on the Directive 92/43/EC as they are accredited as natural habitats for flora and fauna [20]. Despite the constraints, peat is still the primary substrate component, and the exploitation of growing media components for a greener profile of substrates used in agriculture is required [21]. The expanded needs and the intensive vegetables crop cultivation in greenhouses and outdoors, along with the wide broadening of seedling/cutting production at nurseries, exhaust the actual natural sources, including peat [22-24].

Several applications of the solid organic waste (composted olive-mill waste, biochar and compost, composted municipal solid wastes) have been reported in agriculture and eventually used as a medium, either sole or in combination with other material [23,25-28], while diminishing reliance on peat moss [16]. Likewise, paper waste may possibly be used as a constituent in substrates. Efforts should be directed to use the paper waste as a peat replacement for growing media, rather than to conduct exhaustive research to prepare compost derived from the paper mill waste. Previously, on plants grown in PW-media, the fertigation scheme based on complete nutrient solution was proposed, such as the ones applied in techniques with absolute regulation of the fertigation scheme, such as the hydroponic systems [29].

Usage of paper wastes in peat-based growing medium poses benefits; in particular, low levels of toxic elements and pathogens, extensive lifespan, and constant composition over the years [30]. The current work aims to provide additional evidence demonstrating the effectiveness of paper waste added into a growing media, avoiding the time- and energy-demanding processing of composting and waste management, but also providing an effective solution of the use of raw $\mathrm{PW}$ in agriculture by 
farmers. Therefore, it seeks specifically to evaluate the percentage of peat that could be substituted by PW for Brassica seedlings (cauliflower, broccoli, and cabbage) in nursery.

\section{Materials and Methods}

\subsection{Plant Material and Paper Waste}

Three Brassica species were examined in the present study. Seeds of cauliflower F1 Skywalker (Brassica oleracea L. var. botrytis), broccoli F1 Arcadia (Brassica oleracea L. var. cymosa), and cabbage F1 Monroo (Brassica oleracea L. var. capitata) were used. Commercial peat and perlite were purchased. The physicochemical characteristics of perlite have been recorded earlier [31].

Printed paper waste (PW) was derived from common A3-A4 paper sheets shredded into $0.5 \times$ 3-4 cm particles. PW physicochemical characteristics have been evaluated (in dry weight: $\mathrm{dw}$ ) in a previous study [29] and were within limits for growing media [32]. Briefly, PW had pH (pr EN13037) of 6.31; Electrical Conductivity (EC; pr EN 13038) of $1.175 \mathrm{mS} \mathrm{cm}^{-1}(1: 5 \mathrm{v} / \mathrm{v})$; organic matter (pr EN 13039) of $75.52 \% \mathrm{dw}$; organic carbon of $43.81 \% \mathrm{dw}$; $\mathrm{N}$ of $0.37 \% \mathrm{dw}$; ratio $\mathrm{C} / \mathrm{N}$ : 153.9 ; and extraction of calcium chloride/DTPA (CAT) soluble nutrients (pr EN 13651) for K: $2428.5 \mathrm{mg} \mathrm{kg}^{-1}$; P: $389.2 \mathrm{mg} \mathrm{kg}^{-1}$; Ca: $1804.8 \mathrm{mg} \mathrm{kg}^{-1}$; $\mathrm{Mg}: 332.7 \mathrm{mg} \mathrm{kg}{ }^{-1}$; Na: $489.3 \mathrm{mg} \mathrm{kg}^{-1}$; Al: $54.8 \mathrm{mg} \mathrm{kg}^{-1}$; Fe: $85.9 \mathrm{mg} \mathrm{kg}^{-1}$; Mn: $6.8 \mathrm{mg} \mathrm{kg}^{-1}$; $\mathrm{Cu}: 34.6 \mathrm{mg} \mathrm{kg}^{-1}$; Si: $43.6 \mathrm{mg} \mathrm{kg}^{-1}$; Zn: $12.9 \mathrm{mg} \mathrm{kg}^{-1}$. Moreover, heavy metals were below notable levels ( $\mathrm{Ag}, \mathrm{Cd}, \mathrm{Co}, \mathrm{Cr}$, Ti, $\mathrm{Pb}$ ) or beneath lower limits (for instance $\mathrm{Ni}<3.4 \mathrm{mg} \mathrm{kg}^{-1}$ ) [33].

\subsection{Growing Media Properties}

The present research was implemented in a plastic greenhouse at the Cyprus University of Technology. Commercial peat $(\mathrm{P})$ and $\mathrm{PW}$ were used in different ratios $(\mathrm{v} / \mathrm{v})$, to create four growing media named: (1) P only (100\%-control), (2) P:PW (90:10), (3) P:PW (70:30), and (4) P:PW (50:50). Media sufficient aeration was settled by adding perlite $(15 \% \mathrm{v} / \mathrm{v})$ in each of the examined growing media (Figure S1). The PW ratios were chosen based on primary tests and/or earlier ornamental potted plants studies [29].

The chosen growing media were evaluated for their physicochemical characteristics. Total pores space (TPS), available water holding capacity (AWHC), air filled porosity (AFP), and bulk density (BD) were evaluated following the European Standards, EN 13041 [34]. Organic matter and organic $\mathrm{C}$ determined with the Walkley-Black chromic acid wet oxidation method. Electrical conductivity (Mettler Toledo 735, Leicester, UK) and pH (HI-2211 Hanna, Woonsocket, RI, USA) were determined with the 1:5 (v/v) dilution method. Plant tissue was placed in an ashing furnace (Carbolite, AAF 1100, GERO, Germany), at $450^{\circ} \mathrm{C}$ for $6 \mathrm{~h}$, for ashing in porcelain cups. Following hydrochloric $(2 \mathrm{~N} \mathrm{HCl})$ digestion of the sample ash, macro- and micro-nutrients were analyzed with an atomic absorption spectrometer (PG Instruments AA500FG, Leicestershire, UK). The Kjeldahl (BUCHI, Digest automat K-439 and Distillation Kjelflex K-360, Oldham, UK) method was used for total N determination. All chemicals used were analytical grade unless otherwise mentioned in the text.

\subsection{Seed Emergence}

Cauliflower, broccoli, and cabbage seeds were seeded in black plastic seedling trays. Every treatment had 12 replications $\left(40 \mathrm{~cm}^{3}\right.$ wells). Three seeds were seeded in each well. Watering was through mist irrigation daily with $0.5 \mathrm{~min} /$ every $4 \mathrm{~h}$ initially and reached $1.5 \mathrm{~min}$ every $6 \mathrm{~h}$ at a later growing stage of the seedlings. Fertigation (20-20-20) with EC of $1.8 \mathrm{mS} \mathrm{cm}^{-1}$ and the $\mathrm{pH}$ of 5.8, were applied during the plant growth. Air temperature and relative humidity $(\mathrm{RH})$ were varied from $16.4{ }^{\circ} \mathrm{C}$ to $24.4{ }^{\circ} \mathrm{C}$ and $65 \%$ to $75 \% \mathrm{RH}$, respectively.

Seed emergence was recorded on a daily basis and seeds were considered emerged with hypocotyls appearance. Mean emergence time (MET) was calculated as described in previous studies [26]. 


\subsection{Plant Growth and Tissue Analysis}

Seedlings were grown over 1.5 months and then seedling growth was recorded in six seedlings per treatment. The number of leaves and seedling height were measured. Leaf stomatal conductance was measured by using a $\triangle \mathrm{T}$-Porometer AP4 (Delta-T Devices-Cambridge, UK). Leaf chlorophyll fluorescence (chlorophyll fluorometer, opti-sciences OS-30p, UK) was measured on two fully expanded leaves per plant, along with leaf chlorophyll content (six replications/treatment) [35]. Plants were harvested above substrate, upper fresh weight was weighed $(\mathrm{g})$, dried, and total dry matter content (\%) was then computed.

Mineral accumulation in upper part of the plant (including leaves and shoots) was measured on three replications/treatment (two pooled plants/replication) as described previously [36]. The content of nitrogen $(\mathrm{N})$ was determined with Kjeldahl digestion method (BUCHI, Digest automat K-439 and Distillation Kjeldahl K-360, Oldham, UK), while phosphorus (P) spectrophotometrically (Multiskan GO, Thermo Fischer Scientific, USA), and potassium (K), magnesium (Mg), calcium (Ca), sodium $(\mathrm{Na})$, iron $(\mathrm{Fe})$, copper $(\mathrm{Cu})$, manganese $(\mathrm{Mn})$, and zinc $(\mathrm{Zn})$ were determined by an atomic absorption spectrometer (PG Instruments AA500FG, Leicestershire, UK). Results were indicated in $\mathrm{g} \mathrm{kg}^{-1}$ and $\mathrm{mg} \mathrm{kg}^{-1}$ of dry weight, for macro- and micronutrients, respectively.

\subsection{Total Phenolics and Antioxidant Activity}

Methanolic extracts of three samples (two pooled plants/sample) per treatment were used for the total phenolics and total antioxidant activity measurements. For the total phenols content, the Folin-Ciocalteu assay was used according to Tzortzakis et al. [37] and outcomes were indicated as gallic acid equivalents (mg GAE ${ }^{-1}$ of fresh weight). Antioxidant activity was assayed with the ferric reducing antioxidant power (FRAP) and the 2,2-diphenyl-1-picrylhydrazyl (DPPH), as described previously [36]. Outcomes were indicated as trolox equivalents ( $\mathrm{mg}$ trolox $\mathrm{g}^{-1}$ of fresh weight).

\subsection{Lipid Peroxidation, Hydrogen Peroxide, and Antioxidant Enzyme Activity}

Lipid peroxidation and hydrogen peroxide $\left(\mathrm{H}_{2} \mathrm{O}_{2}\right)$ content were determined as reported previously [38,39]. The outcomes were expressed as $\mu \mathrm{mol} \mathrm{H}_{2} \mathrm{O}_{2} \mathrm{~g}^{-1}$ of fresh weight, and lipid peroxidation was computed through the malondialdeyde (MDA) content (nmol of $\mathrm{MDA} \mathrm{g}^{-1}$ of fresh weight).

The enzymes antioxidant activity for superoxide dismutase (SOD) (EC 1.15.1.1), for catalase (CAT) (EC 1.11.1.6), and for peroxidase activity (POD) (EC 1.11.1.6) was assayed as described in Chrysargyris et al. [35]. Results were expressed as enzyme units per mg of protein. Bovine serum albumin was employed as standard for proteins content determination.

\subsection{Statistical Analysis}

Correlation analysis used to examine the interrelations among the studied parameters by using SPSS 24.0 for Windows (SPSS Inc., Chicago, IL, USA). Data were tested for normality and then subjected to analysis of variance (ANOVA). Significant differences were separated by Duncan's multiple range test (DMRT) at $p \leq 0.05$, following one-way ANOVA. Moreover, the datasets were examined by using nonparametric tests and some of them did not show normal distribution; Spearman's correlation coefficients were calculated.

Principal component analysis (PCA) was used for identifying the influence of PW containing growth medium properties on plant parameters by using SPSS software version 24.0 for Windows by IBM Inc. The input variables were the selected properties of growth medium, plant growth and physiology, plant minerals, and plant stress factors and antioxidants. The correlations of studied parameters, which are presented in supplementary documents (Tables S1-S3), were used in the selection of representative properties. $\mathrm{PW}$ was selected to represent bulk density, $\mathrm{pH}, \mathrm{C} / \mathrm{N}, \mathrm{Ca}, \mathrm{Na}, \mathrm{Fe}$, and $\mathrm{Cu}$ in growth medium, since it was the main cause of the changes in these parameters in the growth media and statistically significant strong intercorrelations were present. Organic matter was selected 
to represent the properties decreasing in growth medium with increasing $\mathrm{PW}$ ratio (porosity, container capacity, organic carbon, and nitrogen). Media $\mathrm{K}, \mathrm{P}, \mathrm{Mg}$, and $\mathrm{Zn}$ were excluded from the analysis since they were not dominantly originated neither from $\mathrm{PW}$ nor peat. Therefore, $\mathrm{PW}$ ratio and organic matter were the parameters used in PCA to define growth medium. Fresh biomass was selected to represent leaf number, plant height, $\mathrm{Fv} / \mathrm{Fm}$, and dry weight due to their strong intercorrelations. Similarly, total hlorophyll was used to represent chlorophyll types. As a result, Fresh Biomass, SPAD, Stomatal Conductance, and Total Chlorophyll were used to define plant growth and physiology in PCA. All studied parameters related to plant minerals (N, P, K, Ca, Na, Fe, Cu, and $\mathrm{Zn}$ ) were included in PCA. Major parameters, namely Phenols, DPPH, MDA, $\mathrm{H}_{2} \mathrm{O}_{2}$, and SOD, were used to represent plant stress factors and antioxidants.

For identification of the major influences on plant properties, principal component analysis was used by considering Varimax rotation with Kaiser Normalization. Eigenvalues greater than 1.0 and significant clusters defined by principal components (PCs) with coefficients higher than 0.5 were applied.

\section{Results and Discussion}

\subsection{Growing Media Characteristics}

The PW presence in various ratios impacted the growing media characteristics as shown in Table 1. The addition of up to $30 \%$ PW augmented growing media bulk density compared to the control (100\% peat) treatment while the $50 \%$ PW decreased the bulk density of the media. The presence of PW in the media reduced the available water and air levels at the plant's roots (as displayed by the reduction in the air-filled porosity), and this resulted in the decreased total porosity of the growing media, with more marked effects at the higher PW levels i.e., 50\% of PW. Considering the lower available water and air in the roots on the PW-based growing media, it highlights the importance of optimized irrigation practices during seedling growth at a nursery, by decreasing both the amount and the frequency of the irrigated water in order to avoid hypoxia (low $\mathrm{O}_{2}$ levels) and flooding symptoms. Abad et al. [21] reported the required $\left(<0.4 \mathrm{~g} / \mathrm{cm}^{3}\right)$ BD levels of a growing media, indicating that the BD levels were within the required limits in the present study. The size and probably the shape of paper waste used might change the AFP, whilst folded PW could probably have an influence on AFP. Similar observations were found in ornamental (marigold, petunia, matthiola) pot plants with the use of PW in similar ratio to the present study, but plants were grown hydroponically [29] or when Brasssica seedling production took place with olive-mill waste growing media at various levels (0-20-40-60\%) [22]. Contrasting results have been obtained with the use of sewage sludge-based compost for the production of Pinus pinea seedlings [40]. Adding PW into the growing media decreased organic matter and organic carbon, however all the studied growing media were characterized as rich (varied from $92.44 \%$ to $99.02 \%$ organic matter) in organic matter. The $\mathrm{PW}$-based growing media had high $\mathrm{C} / \mathrm{N}$ ratios due to the low $\mathrm{N}$ content, and this could cause $\mathrm{N}$ shortage due to organic material decomposition through time and as a consequence, this could have resulted in soluble $\mathrm{N}$ immobilization at inadequate levels, into the growing media [24]. However, mineral deficiencies, including N, can be successfully overcome by proper fertigation strategy [29].

The addition of PW into the growing media increased the EC from 277.16 to $719.07 \mu \mathrm{S} \mathrm{cm}^{-1}$ from $100 \%$ peat to $50 \% \mathrm{PW}$, respectively (Table 1 ). However, only in cases of $\leq 30 \% \mathrm{PW}$, the EC values were within limits [21]. The increased EC of a growing media is related to the material rich in minerals that could be possible available for plants uptake [41]. Therefore, the PW addition into the growing media increased the levels of $\mathrm{Ca}, \mathrm{Na}, \mathrm{Fe}$, and $\mathrm{Cu}$ but decreased the levels of $\mathrm{N}$ and $\mathrm{Zn}$. The levels of $\mathrm{Mg}$ were increased in 10 and $50 \%$ of PW-based growing media when compared to the $100 \%$ peat. The levels of $\mathrm{K}, \mathrm{P}$, and Mn did not change among the examined growing media. However, the availability and absorption of the minerals is related to the $\mathrm{pH}$ value of the growing media. The $\mathrm{PW}$ adding increased (almost 1.5 units) the $\mathrm{pH}$, from 4.68 to 6.16 from $100 \%$ peat to $50 \% \mathrm{PW}$, respectively, being consistent with previous studies [42]. He et al. [43] suggested that the increased $\mathrm{pH}$ by using paper mill wastes can 
be efficient for $\mathrm{pH}$ correction of soils with acidity problems or growing material with acidic $\mathrm{pH}$, such as brown peat. At low (acidic) $\mathrm{pH}$, the availability of $\mathrm{N}, \mathrm{P}, \mathrm{K}, \mathrm{Ca}$, and $\mathrm{Mg}$ is poor, whilst micronutrients can get into toxic levels [44]. In the current work, the PW-based media increased availability of $\mathrm{Ca}, \mathrm{Fe}$, $\mathrm{Zn}$, and $\mathrm{Cu}$ (Table 1). It was noticeable that colored waste papers may contain significant amounts of heavy metals as reported by Mertoglu-Elmas [45].

Table 1. Substrate (peat-P, paper waste-PW) physicochemical properties in four mixtures.

\begin{tabular}{ccccc}
\hline & P:PW (100:0) & P:PW (90:10) & P:PW (70:30) & P:PW (50:50) \\
\hline $\mathrm{EC}\left(\mu \mathrm{cm}^{-1}\right)$ & $277.16 \pm 4.50 \mathrm{c}$ & $405.88 \pm 23.99 \mathrm{~b}$ & $412.01 \pm 17.79 \mathrm{~b}$ & $719.07 \pm 8.98 \mathrm{a}$ \\
$\mathrm{pH}$ & $4.68 \pm 0.08 \mathrm{~d}$ & $5.09 \pm 0.17 \mathrm{c}$ & $5.70 \pm 0.02 \mathrm{~b}$ & $6.16 \pm 0.03 \mathrm{a}$ \\
Organic matter $(\%)$ & $99.02 \pm 0.29 \mathrm{a}$ & $97.19 \pm 0.43 \mathrm{ab}$ & $96.41 \pm 0.59 \mathrm{~b}$ & $92.44 \pm 0.80 \mathrm{c}$ \\
Organic C $(\%)$ & $57.44 \pm 0.17 \mathrm{a}$ & $56.37 \pm 0.25 \mathrm{ab}$ & $55.92 \pm 0.34 \mathrm{~b}$ & $53.62 \pm 0.46 \mathrm{c}$ \\
$\mathrm{C} / \mathrm{N}$ & $132.21 \pm 0.59 \mathrm{c}$ & $151.10 \pm 2.93 \mathrm{~b}$ & $156.59 \pm 0.65 \mathrm{~b}$ & $171.83 \pm 9.15 \mathrm{a}$ \\
$\mathrm{N}\left(\mathrm{g} \mathrm{kg}^{-1}\right)$ & $4.33 \pm 0.02 \mathrm{a}$ & $3.72 \pm 0.06 \mathrm{~b}$ & $3.61 \pm 0.01 \mathrm{~b}$ & $3.13 \pm 0.14 \mathrm{c}$ \\
$\mathrm{K}\left(\mathrm{g} \mathrm{kg}^{-1}\right)$ & $0.068 \pm 0.002 \mathrm{a}$ & $0.061 \pm 0.005 \mathrm{a}$ & $0.071 \pm 0.007 \mathrm{a}$ & $0.079 \pm 0.004 \mathrm{a}$ \\
$\mathrm{P}\left(\mathrm{g} \mathrm{kg}^{-1}\right)$ & $0.072 \pm 0.007 \mathrm{a}$ & $0.041 \pm 0.001 \mathrm{a}$ & $0.062 \pm 0.016 \mathrm{a}$ & $0.057 \pm 0.002 \mathrm{a}$ \\
$\mathrm{Ca}\left(\mathrm{g} \mathrm{kg}^{-1}\right)$ & $1.21 \pm 0.02 \mathrm{c}$ & $1.57 \pm 0.08 \mathrm{c}$ & $5.98 \pm 0.16 \mathrm{~b}$ & $11.71 \pm 1.38 \mathrm{a}$ \\
$\mathrm{Mg}\left(\mathrm{mg} \mathrm{kg}^{-1}\right)$ & $0.273 \pm 0.003 \mathrm{c}$ & $0.414 \pm 0.028 \mathrm{a}$ & $0.303 \pm 0.013 \mathrm{bc}$ & $0.342 \pm 0.005 \mathrm{~b}$ \\
$\mathrm{Na}\left(\mathrm{mg} \mathrm{kg}^{-1}\right)$ & $0.138 \pm 0.009 \mathrm{c}$ & $0.232 \pm 0.239 \mathrm{bc}$ & $0.274 \pm 0.031 \mathrm{~b}$ & $0.501 \pm 0.043 \mathrm{a}$ \\
$\mathrm{Fe}\left(\mathrm{mg} \mathrm{kg}^{-1}\right)$ & $570.80 \pm 10.36 \mathrm{c}$ & $583.13 \pm 11.59 \mathrm{c}$ & $667.01 \pm 6.21 \mathrm{~b}$ & $1118.25 \pm 6.89 \mathrm{a}$ \\
$\mathrm{Cu}\left(\mathrm{mg} \mathrm{kg}^{-1}\right)$ & $53.93 \pm 6.70 \mathrm{~b}$ & $75.62 \pm 5.51 \mathrm{ab}$ & $75.89 \pm 8.14 \mathrm{ab}$ & $90.51 \pm 11.10 \mathrm{a}$ \\
$\mathrm{Zn}\left(\mathrm{mg} \mathrm{kg}^{-1}\right)$ & $32.13 \pm 1.75 \mathrm{a}$ & $13.46 \pm 0.93 \mathrm{c}$ & $16.55 \pm 0.91 \mathrm{bc}$ & $20.23 \pm 1.83 \mathrm{~b}$ \\
$\mathrm{Mn}\left(\mathrm{mg} \mathrm{kg}^{-1}\right)$ & $30.05 \pm 17.40 \mathrm{a}$ & $22.14 \pm 7.69 \mathrm{a}$ & $19.55 \pm 11.32 \mathrm{a}$ & $7.66 \pm 4.42 \mathrm{a}$ \\
$\mathrm{TP}(\%) \mathrm{Z}$ & $84.87 \pm 0.27 \mathrm{a}$ & $82.94 \pm 0.28 \mathrm{~b}$ & $77.26 \pm 0.26 \mathrm{c}$ & $75.93 \pm 0.25 \mathrm{~d}$ \\
$\mathrm{AWHC} \%)^{\mathrm{Z}}$ & $68.42 \pm 0.23 \mathrm{a}$ & $66.95 \pm 0.18 \mathrm{~b}$ & $65.74 \pm 0.21 \mathrm{c}$ & $65.94 \pm 0.22 \mathrm{c}$ \\
$\mathrm{AFP} \%)^{\mathrm{Z}}$ & $16.49 \pm 0.05 \mathrm{a}$ & $15.98 \pm 0.05 \mathrm{~b}$ & $11.49 \pm 0.04 \mathrm{c}$ & $9.99 \pm 0.03 \mathrm{~d}$ \\
$\mathrm{BD}\left(\mathrm{g} \mathrm{cm}^{-3}\right) \mathrm{Z}$ & $0.236 \pm 0.003 \mathrm{c}$ & $0.210 \pm 0.000 \mathrm{~d}$ & $0.256 \pm 0.003 \mathrm{~b}$ & $0.273 \pm 0.002 \mathrm{a}$ \\
\hline Total porosity (TP), available water holding capacity (AWHC), air filled porosity (AFP), bulk density (BD) \\
by volume.
\end{tabular}

Intercorrelations media properties observed that; bulk density, $\mathrm{EC}, \mathrm{pH}, \mathrm{C} / \mathrm{N}, \mathrm{Ca}, \mathrm{Na}, \mathrm{Fe}$, and $\mathrm{Cu}$ levels in growth media increased with increasing ratio of $\mathrm{PW}$, while porosity, container capacity, organic matter, carbon, and nitrogen levels were decreased (Table S1). These two groups of parameters also had statistically significant intercorrelations with their members ( $p \leq 0.05) . \mathrm{K}, \mathrm{P}, \mathrm{Mg}, \mathrm{Zn}$, and $\mathrm{Mn}$ did not show statistically significant correlations not only with increasing PW amount in media, but also with most of the other media parameters, which indicated that their concentrations in peat and PW were similar.

\subsection{Seed Emergence}

The seed emergence under nursery conditions was investigated and the findings showed that the first seed emerged on the fifth day for cauliflower and broccoli and on the sixth days for cabbage, whereas the emergence of seeds was completed within $11 \mathrm{~d}$ after seeding (Figure 1). Therefore, seed emergence of cauliflower was decreased up to $19.5 \%$ with the adding of PW at the 11 th day, with a more noticeable effect at the $30 \%$ of PW (Figure 1A). This resulted in a significant $(p<0.05)$ increase (up to $11.7 \%$ ) of MET (virtually $1 \mathrm{~d}$ of delay) for the $30 \%$ PW compared with the control (peat of $100 \%$ ) treatment (Figure 1B). With regards to broccoli, seed emergence reduced (up to 19.5\%) with the presence of PW in comparison with the control treatment (Figure 1C) while no changes were evidenced on MET (Figure 1D). Cabbage seed emergence increased (up to 17.2\%) at the 30\% PW with significant $(p<0.05)$ differences at the last days of emergence period (i.e., days 10-11) (Figure 1E). MET decreased in $30 \%$ PW when compared to the $10 \%$ PW and control (Figure 1F). Generally speaking, the seed MET did not vary much among the examined PW ratios in the growing media, implying that the PW ratio had no sound impacts on seeds during germination and emergence stage. However, growing media based on olive leaves and stones wastes with perlite in various ratios improved seed germination when 
compared with growing media of olive wastes with peat [26]. Comparable stimulatory effect was not evidenced in the current study, with the exception the $30 \%$ of PW in cabbage, and this is possible linked to the different plant species (lettuce and endives versus cauliflower, broccoli, and cabbage in the present study) and raw material (olive stone/pulp waste versus paper waste in the present work). The delays of eggplant seed emergence when various growing media used with municipal solid waste compost and peat could be alleviated by the application of fertigation throughout the seedling growing period [23], indicating the importance of the seedlings' proper nutrient status during plant growth and the fertigation management that should be followed during seedling production.
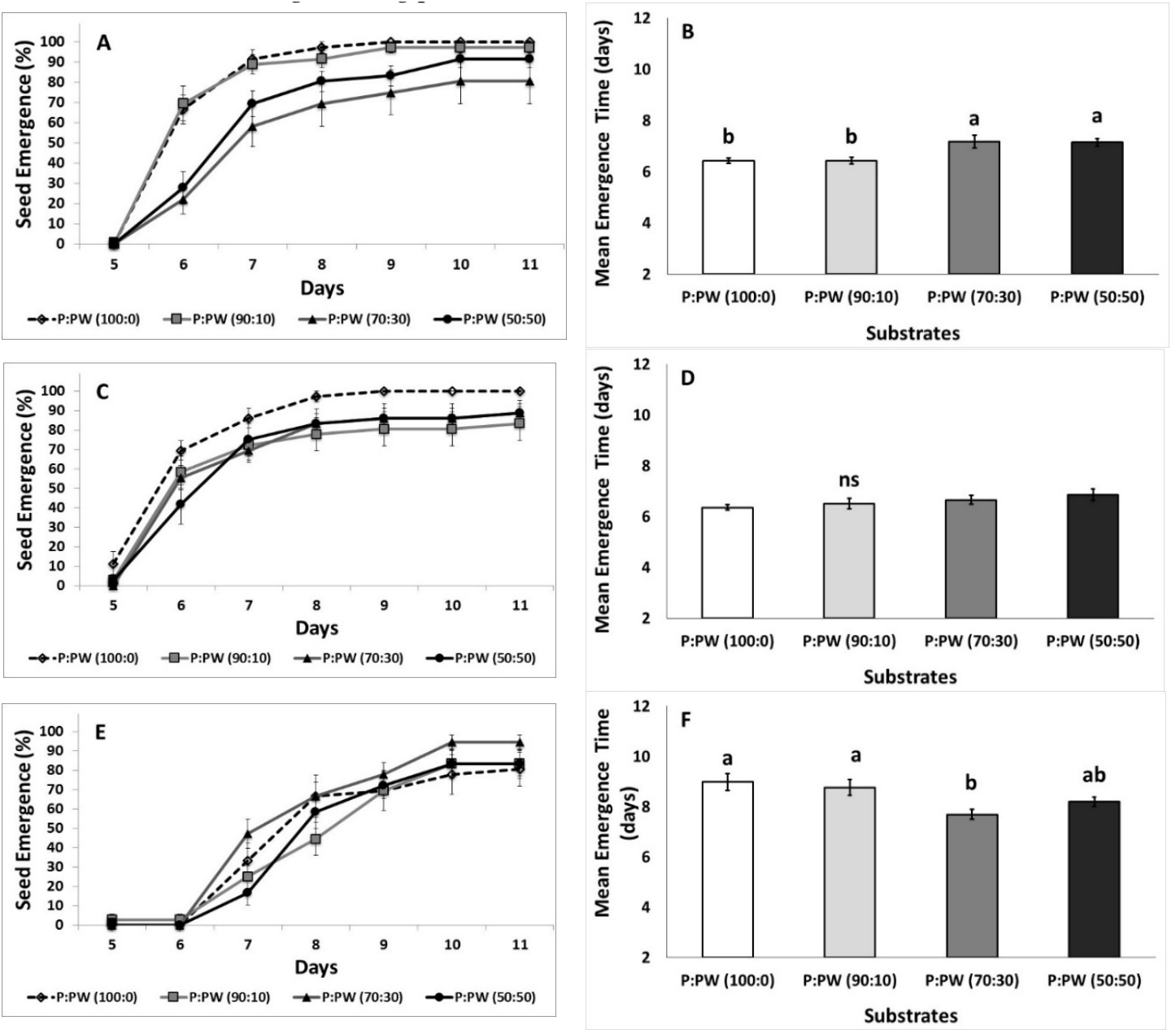

Figure 1. Effect of substrate media (peat-P, paper waste- $P W$ ) on cumulative seedling emergence and mean emergence time of cauliflower $(\mathbf{A}, \mathbf{B})$, broccoli $(\mathbf{C}, \mathbf{D})$, and cabbage $(\mathbf{E}, \mathbf{F})$ seeds germinated in greenhouse nursery. Values represent mean $( \pm \mathrm{SE})$ of measurements made on 12 independent replications (three seeds per well) per treatment. Mean values followed by the same letter do not differ significantly at $p \geq 0.05$ according to Duncan's MRT.

\subsection{Plant Growth and Physiology}

The effects of PW on plant growth and physiology are presented in Table 2. Therefore, PW decreased plant height (up to $33.8 \%, 26.9 \%$, and $23.3 \%$ ), leaf number (up to $42.2 \%, 27.5 \%$, and $34.5 \%$ ), and plant fresh weight (up to $68.0 \%, 61.8 \%$, and $70.0 \%$ ) for cauliflower, broccoli, and cabbage, respectively (Table 2). Larger decreases were evidenced in higher ratios of 30 and $50 \%$ of PW. The production of shorter seedlings, as observed by the decrease of plant height, under nursery conditions is not inevitably a disadvantage whereas it can be practical during growth and transport of draft seedlings, at a nursery enterprise. This was observed mainly in $\geq 30 \% \mathrm{PW}$ for the cauliflower and cabbage and in 
$\geq 10 \%$ PW for the broccoli. Biomass (upper plant part) production declined with the PW addition into the growing media and thus, considering the decreased plant growth and biomass is reflecting that plants grown in growing media with different PW ratio delayed plant growth metabolism. In general, the plant dry matter content did not change among the various growing media used and/or Brassica species, except for the reduced dry matter content found in 30\% PW when compared to $10 \% \mathrm{PW}$ in cauliflower. Plant growth reduction in this work is consistent with the decreased growth in lettuce and chicory seedlings when $50 \%$ olive-mill waste (olive stone/pulp) was used in the growing media [26]. Earlier reports on broccoli grown in 30\% sewage sludge compost obtained plant growth increase but $>30 \%$ ratios resulted in salt accumulation in roots and reduced plant growth [46]. This is possibly the case for the 50\% PW with the increased EC value, out of the required limits [21] in the current study. Therefore, the decreased plant growth observed in PW-based media was mainly related to the physical substrate's characteristics, for instance the decreased total and air pores space and to a lesser extent of the mineral availability. In the future, the possible recovery of plants following transplanting into the soil or sub-transplanting in another growing media with increased AFP can be examined.

Table 2. Impact of substrate (peat-P, paper waste-PW) on cauliflower, broccoli, and cabbage seedlings height ( $\mathrm{cm} \mathrm{plant}^{-1}$ ), leaf number, upper part fresh weight (fw; g plant ${ }^{-1}$ ), and dry matter content (dmc; $\%$ ) on plants grown in greenhouse/nursery.

\begin{tabular}{cccccc}
\hline Species & Substrates & Plant Height & Leaf No & Fresh Weight & Dry Matter \\
\hline Cauliflower & P:PW (100:0) & $7.98 \pm 0.31 \mathrm{a}^{\mathrm{Y}}$ & $6.33 \pm 0.21 \mathrm{a}$ & $5.78 \pm 1.11 \mathrm{a}$ & $11.89 \pm 0.44 \mathrm{ab}$ \\
& P:PW (90:10) & $8.63 \pm 0.19 \mathrm{a}$ & $5.33 \pm 021 \mathrm{~b}$ & $4.83 \pm 0.73 \mathrm{ab}$ & $16.31 \pm 3.40 \mathrm{a}$ \\
& P:PW (70:30) & $5.88 \pm 0.26 \mathrm{~b}$ & $4.66 \pm 0.33 \mathrm{~b}$ & $2.92 \pm 0.81 \mathrm{bc}$ & $9.36 \pm 0.37 \mathrm{~b}$ \\
& P:PW (50:50) & $5.28 \pm 0.15 \mathrm{~b}$ & $3.66 \pm 0.51 \mathrm{c}$ & $1.85 \pm 0.48 \mathrm{c}$ & $11.16 \pm 0.48 \mathrm{ab}$ \\
\hline Broccoli & P:PW (100:0) & $12.11 \pm 0.41 \mathrm{a}$ & $6.66 \pm 0.33 \mathrm{a}$ & $6.85 \pm 0.58 \mathrm{a}$ & $10.82 \pm 1.13 \mathrm{a}$ \\
& P:PW (90:10) & $11.72 \pm 0.36 \mathrm{~b}$ & $5.83 \pm 0.16 \mathrm{~b}$ & $5.06 \pm 0.34 \mathrm{~b}$ & $12.18 \pm 0.69 \mathrm{a}$ \\
& P:PW (70:30) & $9.96 \pm 0.29 \mathrm{c}$ & $5.16 \pm 0.17 \mathrm{c}$ & $3.28 \pm 0.33 \mathrm{c}$ & $11.81 \pm 0.49 \mathrm{a}$ \\
& P:PW (50:50) & $8.85 \pm 0.21 \mathrm{~d}$ & $4.83 \pm 0.16 \mathrm{c}$ & $2.62 \pm 0.20 \mathrm{c}$ & $10.94 \pm 0.58 \mathrm{a}$ \\
\hline Cabbage & P:PW (100:0) & $8.08 \pm 0.35 \mathrm{a}$ & $7.66 \pm 0.21 \mathrm{a}$ & $6.76 \pm 0.93 \mathrm{a}$ & $11.78 \pm 1.76 \mathrm{a}$ \\
& P:PW (90:10) & $7.51 \pm 0.28 \mathrm{ab}$ & $6.66 \pm 0.21 \mathrm{~b}$ & $4.65 \pm 0.23 \mathrm{~b}$ & $10.16 \pm 0.29 \mathrm{a}$ \\
& P:PW (70:30) & $6.81 \pm 0.23 \mathrm{bc}$ & $5.67 \pm 0.20 \mathrm{c}$ & $2.23 \pm 0.34 \mathrm{c}$ & $9.45 \pm 1.50 \mathrm{a}$ \\
& P:PW (50:50) & $6.20 \pm 0.26 \mathrm{c}$ & $5.02 \pm 0.45 \mathrm{c}$ & $2.03 \pm 0.46 \mathrm{c}$ & $8.58 \pm 0.81 \mathrm{a}$ \\
\hline
\end{tabular}

${ }^{Y}$ values ( $\mathrm{n}=6$ for plant height and leaf number; $\mathrm{n}=3$ for fresh weight and dry matter content) in columns followed by the same letter for difference Brassica species are not significantly different, $p<0.05$.

The presence of PW decreased leaf stomatal conductance of cauliflower and broccoli at $\geq 30 \% \mathrm{PW}$ compared with the $100 \%$ peat, namely control treatment (Table 3). In the case of cabbage, leaf stomatal conductance decreased at $\geq 30 \%$ PW compared with the $10 \%$ PW treatment. Stomatal closure is a plant adaptation mechanism towards stress or specific environmental conditions, and the outcomes of the present research are in accordance with earlier studies on the closure of stomata in Brasssica species grown in mixtures of peat and olive/stone residues [22] and olive mill wastewater-irrigated tomatoes in sand culture [41]. Chlorophyll production decreased in cauliflower and broccoli at $\geq 50 \% \mathrm{PW}$ and $\geq 30 \% \mathrm{PW}$, respectively. Furthermore, chlorophyll fluorescence declined at $\geq 50 \%$ PW for cauliflower and cabbage and at $\geq 10 \% \mathrm{PW}$ for broccoli. The high ratio of PW in the growing media decreased chlorophyll (Chl a, Chl b and total $\mathrm{Chl}$ ) levels while chlorophylls at the 10\% PW ratio either did not differ from the control treatment in case of cauliflower and cabbage or increased significantly $(p<0.05)$ in the case of broccoli (Table 3). Chlorophyll decrease is related to plant growth reduction for the different PW ratio, in agreeance with previous records [22]. Similar findings were observed when potted ornamental plants were grown in various ratios (0-10-30-50-100\%) of PW [29] or when PW mixed with olive/stone residues [28]. The high level of chlorophylls is an indicator of the photosynthetic performance of the leaves, and as such Kiarostami et al. [47] revealed the reduction in chlorophylls levels with the adequate decrease in plant growth. 
Table 3. Impact of substrate (peat-P, paper waste-PW) on cauliflower, broccoli, and cabbage seedlings chlorophyll fluorescence (Fv/Fm), SPAD value, stomatal conductance $\left(\mathrm{s} \mathrm{cm}^{-1}\right)$, and chlorophylls $\left(\mathrm{Chl} \mathrm{a}, \mathrm{Chl} \mathrm{b}\right.$, total $\left.\mathrm{Chl} ; \mathrm{mg} \mathrm{g}^{-1} \mathrm{Fw}\right)$ content on plants grown in greenhouse/nursery.

\begin{tabular}{cccccccc}
\hline Species & Substrates & Chl. Fluorescence & SPAD & Stomatal Conductance & Chl a & Chl b & Total Chl \\
\hline Cauliflower & P:PW (100:0) & $0.846 \pm 0.003 \mathrm{a}^{\mathrm{Y}}$ & $50.13 \pm 2.94 \mathrm{a}$ & $1.696 \pm 0.308 \mathrm{a}$ & $0.793 \pm 0.046 \mathrm{ab}$ & $0.373 \pm 0.016 \mathrm{ab}$ & $1.166 \pm 0.629 \mathrm{ab}$ \\
& P:PW (90:10) & $0.835 \pm 0.003 \mathrm{ab}$ & $51.30 \pm 3.92 \mathrm{a}$ & $1.093 \pm 0.211 \mathrm{ab}$ & $0.877 \pm 0.038 \mathrm{a}$ & $0.413 \pm 0.018 \mathrm{a}$ & $1.291 \pm 0.057 \mathrm{a}$ \\
& P:PW (70:30) & $0.834 \pm 0.004 \mathrm{ab}$ & $41.43 \pm 3.43 \mathrm{ab}$ & $0.860 \pm 0.085 \mathrm{~b}$ & $0.714 \pm 0.228 \mathrm{~b}$ & $0.345 \pm 0.011 \mathrm{~b}$ & $1.059 \pm 0.034 \mathrm{~b}$ \\
& P:PW (50:50) & $0.824 \pm 0.004 \mathrm{~b}$ & $34.93 \pm 1.70 \mathrm{~b}$ & $0.850 \pm 0.098 \mathrm{~b}$ & $0.517 \pm 0.002 \mathrm{c}$ & $0.267 \pm 0.002 \mathrm{c}$ & $0.784 \pm 0.001 \mathrm{c}$ \\
\hline Broccoli & P:PW (100:0) & $0.821 \pm 0.005 \mathrm{a}$ & $49.76 \pm 1.79 \mathrm{a}$ & $0.860 \pm 0.072 \mathrm{a}$ & $0.821 \pm 0.042 \mathrm{bc}$ & $0.397 \pm 0.015 \mathrm{c}$ & $1.220 \pm 0.057 \mathrm{bc}$ \\
& P:PW (90:10) & $0.830 \pm 0.011 \mathrm{~b}$ & $47.66 \pm 0.73 \mathrm{a}$ & $0.693 \pm 0.046 \mathrm{ab}$ & $0.994 \pm 0.010 \mathrm{a}$ & $0.490 \pm 0.004 \mathrm{a}$ & $1.481 \pm 0.017 \mathrm{a}$ \\
& P:PW (70:30) & $0.816 \pm 0.001 \mathrm{c}$ & $41.46 \pm 1.64 \mathrm{~b}$ & $0.600 \pm 0.052 \mathrm{~b}$ & $0.870 \pm 0.016 \mathrm{~b}$ & $0.435 \pm 0.012 \mathrm{~b}$ & $0.301 \pm 0.028 \mathrm{~b}$ \\
& P:PW (50:50) & $0.813 \pm 0.004 \mathrm{c}$ & $36.56 \pm 1.61 \mathrm{~b}$ & $0.620 \pm 0.040 \mathrm{~b}$ & $0.784 \pm 0.011 \mathrm{c}$ & $0.392 \pm 0.009 \mathrm{c}$ & $0.173 \pm 0.020 \mathrm{c}$ \\
\hline Cabbage & P:PW (100:0) & $0.838 \pm 0.002 \mathrm{a}$ & $39.03 \pm 1.77 \mathrm{a}$ & $1.083 \pm 0.082 \mathrm{ab}$ & $0.779 \pm 0.093 \mathrm{a}$ & $0.374 \pm 0.045 \mathrm{a}$ & $1.150 \pm 0.138 \mathrm{a}$ \\
& P:PW (90:10) & $0.824 \pm 0.012 \mathrm{ab}$ & $39.26 \pm 0.54 \mathrm{a}$ & $1.240 \pm 0.135 \mathrm{a}$ & $0.637 \pm 0.004 \mathrm{ab}$ & $0.323 \pm 0.001 \mathrm{ab}$ & $0.956 \pm 0.003 \mathrm{ab}$ \\
& P:PW (70:30) & $0.825 \pm 0.002 \mathrm{ab}$ & $36.30 \pm 0.55 \mathrm{a}$ & $0.803 \pm 0.049 \mathrm{~b}$ & $0.583 \pm 0.001 \mathrm{~b}$ & $0.270 \pm 0.005 \mathrm{bc}$ & $0.806 \pm 0.008 \mathrm{~b}$ \\
& P:PW (50:50) & $0.807 \pm 0.008 \mathrm{~b}$ & $36.13 \pm 1.87 \mathrm{a}$ & $0.910 \pm 0.051 \mathrm{~b}$ & $0.362 \pm 0.010 \mathrm{c}$ & $0.215 \pm 0.020 \mathrm{c}$ & $0.573 \pm 0.020 \mathrm{c}$ \\
\hline
\end{tabular}

${ }^{Y}$ values $(\mathrm{n}=3)$ in columns followed by the same letter for difference Brassica species are not significantly different, $p<0.05$. 
The impact of the substrate properties on plant growth and physiology was examined. As the PW amount in media has been increased, the number of cauliflower leaves, plant height, Fv/Fm, fresh biomass, dry matter, and SPAD were decreased (Table S2). Since bulk density, EC, pH, C/N, Ca, Na, $\mathrm{Fe}$, and $\mathrm{Cu}$ levels were all well correlated with $\mathrm{PW}$ amount in media, their impact on the number of leaves, plant height, Fv/Fm, fresh biomass, dry matter, and SPAD were also negative. However, the chlorophyll types (Chl-a, Chl-b, and total $\mathrm{Chl}$ ) were only found negatively correlated with container capacity ( $\mathrm{r}:-0.671-0.692, p \leq 0.05)$ and zinc levels in the media ( $\mathrm{r}:-0.627-0.748, p \leq 0.01)$. Stomatal conductance showed negative correlations with $\mathrm{Mg}(\mathrm{r}:-0.581, p<0.05)$ and $\mathrm{Cu}(\mathrm{r}:-0.634, p<0.05)$, and a positive correlation with $\mathrm{Zn}(\mathrm{r}: 0.588, p<0.05)$.

The $\mathrm{PW}$ amount, bulk density, EC, $\mathrm{pH}, \mathrm{C} / \mathrm{N}, \mathrm{Ca}, \mathrm{Na}$, and Fe showed negative correlations with most of the parameters showing broccoli growth (leaf number, height, Fv/Fm, fresh biomass, dry weight, SPAD, and stomatal conductance; $r>-0.500$ and $p \leq 0.05$ ) (Table S3). Similar to the results obtained for cauliflower, the chlorophyll types in broccoli (Chl-a, Chl-b, and total Chl) were found negatively correlated with container capacity $(\mathrm{r}:-0.580-0.643, \mathrm{p} \leq 0.05)$ and the zinc levels in the media (r: $-0.727-0.776, p \leq 0.01)$.

Increasing the share of PW in growing media has been found to be negatively correlated with cabbage leaf number, its height, Fv/Fm, fresh biomass, and dry matter, as well as chlorophyll types. Plant height had a negative correlation with media K ( $r>-0.753, p<0.01)$, while Fv/Fm also showed negative correlations with $\mathrm{EC}, \mathrm{C} / \mathrm{N}, \mathrm{K}$, and $\mathrm{Na}$. Media $\mathrm{pH}$ and $\mathrm{Ca}$ were also showed statistically strong $(\mathrm{r}>-0.650, p<0.05)$ negative correlations with the same plant parameters (Table S4). All chlorophyll types were also well correlated with media porosity, organic matter, carbon and nitrogen in the media, which increased with elevated PW ratio $(r>0.500, p<0.05)$. However, it was seen that strong negative correlations were present between chlorophyll types and media $\mathrm{EC}, \mathrm{pH}, \mathrm{C} / \mathrm{N}, \mathrm{Ca}, \mathrm{Mg}, \mathrm{Na}$, and $\mathrm{Cu}$ levels $(r>0.600, p<0.05)$; that was not observed for other studied plants.

In general, leaf number, plant height, $\mathrm{Fv} / \mathrm{Fm}$, fresh biomass, and dry weight of the studied plants were all well correlated with organic matter, organic carbon, and total nitrogen levels, whose levels increased with increasing PW ratio in the media.

\subsection{Plant Minerals}

Table 4 shows the mineral content for the examined Brasssica species. In cauliflower, $\mathrm{N}, \mathrm{K}$, and $\mathrm{P}$ levels increased (up to $61.1 \%, 72.6$, and $40.2 \%$, respectively) with the PW adding greater levels in $30 \%$ of PW. However, Na and Fe content reduced up to $32.9 \%$ and $42.2 \%$, respectively, with the PW adding into the growing media. The highest content for $\mathrm{Mg}$ (averaged in $3.17 \mathrm{~g} \mathrm{~kg}^{-1}$ ), Ca (averaged in $12.21 \mathrm{~g} \mathrm{~kg}^{-1}$ ), and $\mathrm{Cu}$ (averaged in $43.95 \mathrm{mg} \mathrm{kg}^{-1}$ ), was observed in $50 \%$ of PW while the highest $\mathrm{Zn}$ accumulation (averaged in $115.39 \mathrm{mg} \mathrm{kg}^{-1}$ ) was observed in $10 \%$ of PW. In broccoli, $\mathrm{N}$ and P content increased in $50 \% \mathrm{PW}$ while K accumulated in $\geq 30 \% \mathrm{PW}$. The content of $\mathrm{Mg}$ and Fe decreased (up to $39.4 \%$ and $42.8 \%$, respectively) with the PW presence in the growing media. The highest levels of Ca (averaged in $7.74 \mathrm{~g} \mathrm{~kg}^{-1}$ ) and $\mathrm{Cu}$ (averaged in $40.60 \mathrm{mg} \mathrm{kg}^{-1}$ ) were found in $50 \%$ of PW while the highest $\mathrm{Na}$ (averaged in $10.14 \mathrm{~g} \mathrm{~kg}^{-1}$ ) and $\mathrm{Zn}$ (averaged in $187.20 \mathrm{mg} \mathrm{kg}^{-1}$ ) were found in $10 \%$ of $\mathrm{PW}$. In cabbage, N, K, and P accumulated at increased levels in case of $30 \% \mathrm{PW}, \mathrm{Mg}, \mathrm{Na}, \mathrm{Cu}$ and $\mathrm{Zn}$ accumulated greatly in $50 \% \mathrm{PW}$ and Ca accumulated in $\geq 30 \% \mathrm{PW}$. In contrast, Fe highly accumulated in $\leq 10 \%$ of PW. The addition of PW in increased amount resulted in N, K, P, Ca, Cu, and Zn mineral accumulation in different Brassica species. The mineral content in PW-based media was adequate or excessive (without causing any phytotoxicity) [48] and in vermicomposted PW-based media [14]. However, the low plant growth, the reduced content of chlorophylls, and the decreased photosynthetic rates can be justified because of the irrelevant growing media physicochemical characteristics, as has been reported previously $[29,41]$.

The impact of media properties on plant minerals revealed that $\mathrm{P}, \mathrm{Ca}$, and $\mathrm{Cu}$ levels in cauliflower plant increased with increasing PW in the growing media $(p<0.01)$, while plant Na and Fe levels decreased $(p<0.01)$ (Table S5). Media organic matter, porosity, organic carbon, and nitrogen levels 
showed strong positive correlations with plant $\mathrm{Na}$ and Fe levels $(p<0.01)$. None of the growth medium elemental levels were found correlated with its cauliflower levels, except $\mathrm{Na}$, which showed a negative impact. Media P and Mn levels did not show any correlation with any of the plant minerals. The following statistically significant positive correlations among media $(\mathrm{m})$ and cauliflower $\left({ }_{\mathrm{cf}}\right)$ levels of minerals were detected; $\mathrm{K}_{\mathrm{m}}$ vs. $\mathrm{Mg}_{\mathrm{cf}}$ and $\mathrm{Cu}_{\mathrm{cf}}, \mathrm{Mg}_{\mathrm{m}}$ vs. $\mathrm{Zn}_{\mathrm{cf}}, \mathrm{Na}_{\mathrm{m}}$ vs. $\mathrm{Ca}_{\mathrm{cf}}, \mathrm{Fe}_{\mathrm{m}}$ vs. $\mathrm{P}_{\mathrm{cf}}, \mathrm{Ca}_{\mathrm{cf}}$, and $\mathrm{Cu}_{\mathrm{cf}}, \mathrm{Cu}_{\mathrm{m}}$ vs. $\mathrm{K}_{\mathrm{cf}}$ and $\mathrm{Ca}_{\mathrm{cf}}, \mathrm{Zn}_{\mathrm{m}}$ vs.Mg $\mathrm{Mg}_{\mathrm{cf}}$, while the negative correlations were as follows: $\mathrm{K}_{\mathrm{m}}$ vs. $\mathrm{Fe}_{\mathrm{cf}}, \mathrm{Mg}_{\mathrm{m}}$ vs. $\mathrm{Fe}_{\mathrm{cf}}, \mathrm{Na}_{\mathrm{m}}$ vs. $\mathrm{Na}_{\mathrm{cf}}$ and $\mathrm{Fe}_{\mathrm{cf}}, \mathrm{Fe}_{\mathrm{m}}$ vs. $\mathrm{Na}_{\mathrm{cf}}, \mathrm{Cu}_{\mathrm{m}}$ vs. $\mathrm{Na}_{\mathrm{cf}}$ and $\mathrm{Fe}_{\mathrm{cf}}, \mathrm{Zn}_{\mathrm{m}}$ vs. $\mathrm{N}_{\mathrm{cf}}$ and $\mathrm{K}_{\mathrm{cf}}$.

Table 4. Effect of substrate media (peat-P, paper waste-PW) on minerals in cauliflower, broccoli, and cabbage plants. Values are mean $\pm \mathrm{SE}(\mathrm{n}=3)$. In each row, values followed by the same letter do not differ significantly at $p<0.05$.

\begin{tabular}{|c|c|c|c|c|c|}
\hline & Minerals & P:PW (100:0) & P:PW (90:10) & P:PW (70:30) & P:PW (50:50) \\
\hline \multirow[t]{9}{*}{ Cauliflower } & $\mathrm{N}\left(\mathrm{g} \mathrm{kg}^{-1}\right)$ & $22.14 \pm 0.17 \mathrm{~d}$ & $27.14 \pm 0.16 b$ & $35.67 \pm 0.84 a$ & $25.03 \pm 0.17 c$ \\
\hline & $\mathrm{K}\left(\mathrm{g} \mathrm{kg}^{-1}\right)$ & $29.37 \pm 0.03 c$ & $37.37 \pm 0.23 b$ & $50.69 \pm 0.17 a$ & $36.65 \pm 0.51 b$ \\
\hline & $\mathrm{P}\left(\mathrm{g} \mathrm{kg}^{-1}\right)$ & $5.84 \pm 0.08 c$ & $6.91 \pm 0.03 b$ & $8.19 \pm 0.12 a$ & $7.26 \pm 0.15 b$ \\
\hline & $\operatorname{Mg}\left(\mathrm{g} \mathrm{kg}^{-1}\right)$ & $2.45 \pm 0.09 b$ & $1.42 \pm 0.01 c$ & $1.36 \pm 0.03 c$ & $3.17 \pm 0.02 a$ \\
\hline & $\mathrm{Ca}\left(\mathrm{g} \mathrm{kg}^{-1}\right)$ & $5.16 \pm 0.08 c$ & $5.88 \pm 0.14 c$ & $8.70 \pm 0.38 b$ & $12.21 \pm 1.14 a$ \\
\hline & $\mathrm{Na}\left(\mathrm{g} \mathrm{kg}^{-1}\right)$ & $15.99 \pm 0.01 a$ & $11.84 \pm 0.18 b$ & $11.74 \pm 0.02 b$ & $10.73 \pm 0.19 c$ \\
\hline & $\mathrm{Fe}\left(\mathrm{mg} \mathrm{kg}^{-1}\right)$ & $62.68 \pm 1.96 a$ & $46.77 \pm 1.10 b$ & $50.90 \pm 1.62 b$ & $36.21 \pm 4.35 c$ \\
\hline & $\mathrm{Cu}\left(\mathrm{mg} \mathrm{kg}^{-1}\right)$ & $21.42 \pm 0.61 c$ & $21.02 \pm 0.49 c$ & $36.23 \pm 0.27 b$ & $43.95 \pm 0.58 a$ \\
\hline & $\mathrm{Zn}\left(\mathrm{mg} \mathrm{kg}^{-1}\right)$ & $50.10 \pm 3.05 c$ & $115.39 \pm 3.66 a$ & $46.86 \pm 0.40 c$ & $78.75 \pm 5.90 b$ \\
\hline \multirow[t]{9}{*}{ Broccoli } & $\mathrm{N}\left(\mathrm{g} \mathrm{kg}^{-1}\right)$ & $23.72 \pm 0.00 b$ & $22.21 \pm 0.03 c$ & $23.22 \pm 0.11 b c$ & $25.85 \pm 0.62 a$ \\
\hline & $\mathrm{K}\left(\mathrm{g} \mathrm{kg}^{-1}\right)$ & $26.83 \pm 0.11 d$ & $30.04 \pm 0.23 c$ & $37.97 \pm 0.80 a$ & $35.40 \pm 0.81 b$ \\
\hline & $P\left(\mathrm{~g} \mathrm{~kg}^{-1}\right)$ & $5.77 \pm 0.00 c$ & $6.47 \pm 0.10 b$ & $6.77 \pm 0.03 b$ & $7.03 \pm 0.15 a$ \\
\hline & $\operatorname{Mg}\left(\mathrm{g} \mathrm{kg}^{-1}\right)$ & $5.64 \pm 0.01 a$ & $5.38 \pm 0.03 b$ & $3.42 \pm 0.03 d$ & $4.62 \pm 0.01 c$ \\
\hline & $\mathrm{Ca}\left(\mathrm{g} \mathrm{kg}^{-1}\right)$ & $7.44 \pm 0.14 \mathrm{ab}$ & $6.78 \pm 0.42 b c$ & $6.33 \pm 0.17 c$ & $7.74 \pm 0.01 a$ \\
\hline & $\mathrm{Na}\left(\mathrm{g} \mathrm{kg}^{-1}\right)$ & $9.49 \pm 0.09 b$ & $10.14 \pm 0.02 a$ & $7.85 \pm 0.00 c$ & $6.83 \pm 0.13 d$ \\
\hline & $\mathrm{Fe}\left(\mathrm{mg} \mathrm{kg}{ }^{-1}\right)$ & $51.14 \pm 0.42 \mathrm{a}$ & $46.02 \pm 0.06 b$ & $34.56 \pm 0.04 c$ & $29.26 \pm 1.10 \mathrm{~d}$ \\
\hline & $\mathrm{Cu}\left(\mathrm{mg} \mathrm{kg}^{-1}\right)$ & $27.78 \pm 1.81 b$ & $30.90 \pm 1.81 b$ & $30.14 \pm 0.25 b$ & $40.60 \pm 1.09 a$ \\
\hline & $\mathrm{Zn}\left(\mathrm{mg} \mathrm{kg}^{-1}\right)$ & $101.89 \pm 4.74 c$ & $187.20 \pm 10.47 a$ & $73.60 \pm 0.37 d$ & $143.73 \pm 5.26 b$ \\
\hline \multirow[t]{9}{*}{ Cabbage } & $\mathrm{N}\left(\mathrm{g} \mathrm{kg}^{-1}\right)$ & $22.72 \pm 0.45 c$ & $23.45 \pm 0.14 b c$ & $32.39 \pm 0.28 a$ & $24.12 \pm 0.16 b$ \\
\hline & $\mathrm{K}\left(\mathrm{g} \mathrm{kg}^{-1}\right)$ & $27.90 \pm 0.22 \mathrm{~d}$ & $32.70 \pm 0.48 c$ & $47.03 \pm 0.83 a$ & $36.80 \pm 1.23 b$ \\
\hline & $\mathrm{P}\left(\mathrm{g} \mathrm{kg}^{-1}\right)$ & $5.79 \pm 0.11 b$ & $5.82 \pm 0.00 b$ & $6.18 \pm 0.09 a$ & $5.78 \pm 0.09 b$ \\
\hline & $\operatorname{Mg}\left(\mathrm{g} \mathrm{kg}^{-1}\right)$ & $4.27 \pm 0.09 c$ & $3.43 \pm 0.04 d$ & $5.42 \pm 0.16 b$ & $6.68 \pm 0.14 a$ \\
\hline & $\mathrm{Ca}\left(\mathrm{g} \mathrm{kg}^{-1}\right)$ & $4.78 \pm 0.30 b$ & $5.43 \pm 0.30 b$ & $8.78 \pm 0.14 a$ & $8.06 \pm 0.26 a$ \\
\hline & $\mathrm{Na}\left(\mathrm{g} \mathrm{kg}^{-1}\right)$ & $7.83 \pm 0.12 \mathrm{ab}$ & $7.01 \pm 0.06 c$ & $7.57 \pm 0.02 b$ & $8.13 \pm 0.11 a$ \\
\hline & $\mathrm{Fe}\left(\mathrm{mg} \mathrm{kg}^{-1}\right)$ & $57.24 \pm 3.16 \mathrm{a}$ & $59.54 \pm 0.97 a$ & $35.71 \pm 2.23 b$ & $36.25 \pm 2.54 b$ \\
\hline & $\mathrm{Cu}\left(\mathrm{mg} \mathrm{kg}^{-1}\right)$ & $32.19 \pm 1.20 c$ & $37.01 \pm 0.04 c$ & $104.32 \pm 4.24 b$ & $120.41 \pm 2.56 a$ \\
\hline & $\mathrm{Zn}\left(\mathrm{mg} \mathrm{kg}^{-1}\right)$ & $23.05 \pm 0.57 \mathrm{~d}$ & $124.42 \pm 3.58 b$ & $87.48 \pm 2.16 c$ & $201.23 \pm 0.99 a$ \\
\hline
\end{tabular}

Since their main source in media was $\mathrm{PW}$, media EC, $\mathrm{pH}, \mathrm{Ca}, \mathrm{Na}$, and Fe were found strongly correlated with broccoli $\mathrm{K}, \mathrm{P}$, and $\mathrm{Cu}$ levels and they were negatively correlated with plant $\mathrm{Mn}, \mathrm{Na}$, and Fe ( $p$ : 0.01-0.05) (Table S6). Media parameters of porosity, container capacity, organic matter, organic carbon, and nitrogen showed very strong positive correlations with $\mathrm{Mg}$, $\mathrm{Na}$, and $\mathrm{Fe}$ in broccoli $(p<0.01)$, and negative correlations with $\mathrm{K}, \mathrm{P}$, and $\mathrm{Cu}(p<0.05)$. Only media Na and Fe levels showed statistically significant, but negative, correlations with their levels in the plant $(p<0.05)$. Other significant positive correlations between media $(\mathrm{m})$ and plant $(\mathrm{bc})$ minerals were; $\mathrm{K}_{\mathrm{m}} \mathrm{vs} . \mathrm{Ca}_{\mathrm{bc}}$ and $\mathrm{Cu}_{\mathrm{bc}}, \mathrm{Mg}_{\mathrm{m}}$ vs. $\mathrm{Zn}_{\mathrm{bc}}, \mathrm{Cu}_{\mathrm{m}}$ vs. $\mathrm{K}_{\mathrm{bc}}$, and $\mathrm{Zn}_{\mathrm{m}}$ vs. $\mathrm{N}_{\mathrm{bc}}$, while the negative correlations were $\mathrm{K}_{\mathrm{m}} \mathrm{vs}$. $\mathrm{Na}_{\mathrm{bc}}$, and $\mathrm{Cu}_{\mathrm{m}}$ vs. $\mathrm{Mg}_{\mathrm{bc}}$. Media and plant $\mathrm{P}$ and $\mathrm{Mn}$ levels did not show and correlations.

For cabbage; media $\mathrm{PW}$ ratio, bulk density, $\mathrm{pH}, \mathrm{Ca}, \mathrm{Na}$, and Fe leaves were strongly correlated with plant $\mathrm{N}, \mathrm{K}, \mathrm{Mg}, \mathrm{Ca}, \mathrm{Cu}, \mathrm{Zn}$ levels $(p<0.05)$ and negatively correlated with plant Fe (Table S7). The opposite was valid for media porosity, container capacity, organic matter, organic carbon, and nitrogen in media. Media EC also showed strong positive correlations with plant $\mathrm{K}, \mathrm{Cu}$, and $\mathrm{Zn}$ levels $(p<0.05)$, and a negative correlation with $\mathrm{Fe}(p<0.01)$. Other positive correlations among media 
(m) and cabbage $\left({ }_{\mathrm{cb}}\right.$ ) elemental levels were $\mathrm{Mg}_{\mathrm{m}}$ vs. $\mathrm{Zn}_{\mathrm{cb}}, \mathrm{Cu}_{\mathrm{m}}$ vs. $\mathrm{K}_{\mathrm{cb}}, \mathrm{Cu}_{\mathrm{cb}}$, and $\mathrm{Zn}_{\mathrm{cb}}, \mathrm{Zn}_{\mathrm{m}}$ vs. $\mathrm{N}_{\mathrm{cb}}$,

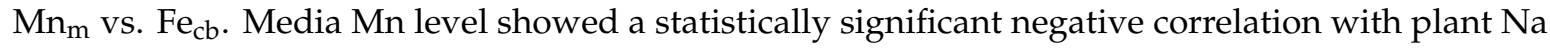
level. Media K and P levels and cabbage P level did not correlate significantly.

According to the present findings, it was understood that media PW ratio and related media parameters influenced the plant mineral compositions, however the response of each studied plants have seen in different parameters. The elements showing increasing values with increased ratio of $\mathrm{PW}$ in media were $\mathrm{P}, \mathrm{Ca}$, and $\mathrm{Cu}$ in cauliflower, $\mathrm{K}, \mathrm{P}$, and $\mathrm{Cu}$ in broccoli, and $\mathrm{N}, \mathrm{K}, \mathrm{Mg}, \mathrm{Ca}, \mathrm{Cu}$, and $\mathrm{Zn}$ in cabbage. The negative impact of increased PW in media on plants was not so similar; $\mathrm{Na}$ and Fe levels decreased in cauliflower, $\mathrm{Mn}, \mathrm{Na}$, and Fe decreased in broccoli, and Fe decreased in cabbage.

\subsection{Plant Stress Factors and Antioxidants}

The impacts of PW on the plant total phenolics and antioxidant status (DPPH, FRAP) are shown in Figure 2. In cauliflower, antioxidant activity as determined by DPPH and FRAP were increased (up to $99.7 \%$ and $38.9 \%$, respectively) in plants grown in $\geq 30 \% \mathrm{PW}$, while no differences were observed on total phenolics (Figure 2A1-C1). Antioxidant activity was also increased in case of cabbage as assayed by DPPH (up to 2.6 times) for $\geq 30 \%$ PW and FRAP (up to 2.5 times) for $\geq 10 \%$ PW, while total phenolics increased (up to $28.1 \%$ ) with the presence of PW into the growing media (Figure 2A3-C3). Indeed, in broccoli, the PW presence did not affect the total phenolics and the antioxidant activity of the examined Brassica species (Figure 2A2-C2).
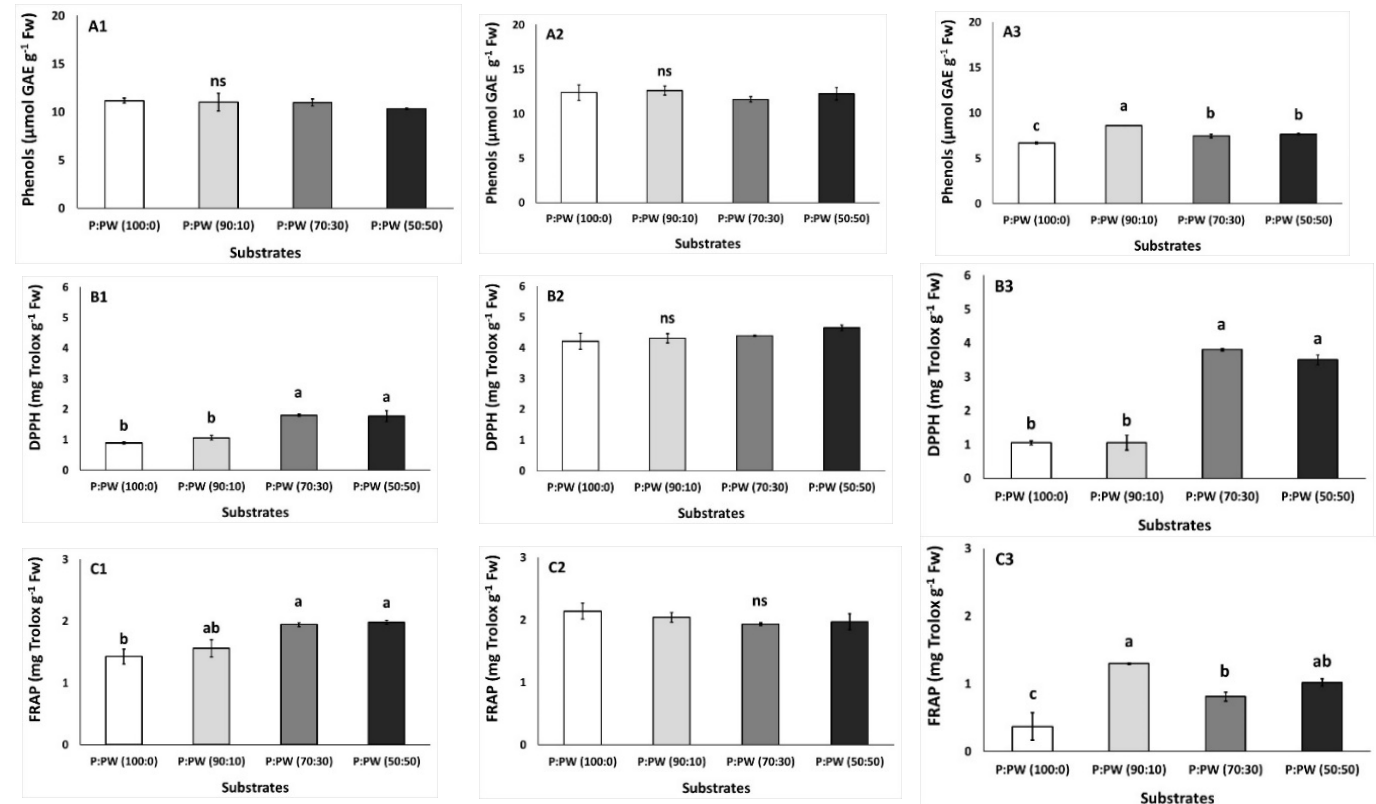

Figure 2. Effect of substrate media (peat-P, paper waste-PW) on total phenolics (mg GAE g ${ }^{-1} \mathrm{Fw}$ ), antioxidant activity (DPPH, FRAP: $\mathrm{mg}$ trolox $\mathrm{g}^{-1} \mathrm{Fw}$ ), in cauliflower (A1-C1), broccoli (A2-C2), and cabbage (A3-C3) plants. Values are mean \pm SE $(n=3)$. Mean values followed by the same letter do not differ significantly at $p \geq 0.05$ according to Duncan's MRT.

During growth, plants are subjected to various stress, rarely one and more commonly combined stress factors, either abiotic or biotic, and they cope with the surplus production of reactive oxygen species (ROS). This causes oxidation damage to the tissue, and plants build mechanisms to detoxify the stress condition. Therefore, detoxification is initiated with the increase of SOD levels towards the toxic effects of the high ROS levels and the consequence is raised $\mathrm{H}_{2} \mathrm{O}_{2}$ levels due to the $\mathrm{O}_{2}{ }^{-}$detoxification, followed by a boost of CAT or peroxidase (POX) activities for $\mathrm{H}_{2} \mathrm{O}_{2}$ decomposition [35,49] and converting the superoxide and hydrogen peroxide molecules to water. A commonly used stress indicator is the MDA synthesis, which is linked with the lipid peroxidation, and is increased during 
stress condition. Lipid peroxidation in raised when plant antioxidants were unable to scavenge ROS. In that sense, several enzymatic (catalase, superoxide dismutase, peroxidases, etc.) and non-enzymatic (proline, ascorbate, etc.) antioxidant mechanisms are induced in order for the plant to detox the observed stress [35]. Considering the levels of MDA and $\mathrm{H}_{2} \mathrm{O}_{2}$ that remained unchanged (Figure 3A2-A3) and/or reduced (Figure 3A1, B1-B3) compared to the control plant (100\% peat), it seems that all the examined Brassica species were not subjected to stress condition due to the PW presence. This is also supported by the fact that in almost all cases, enzymes activities of SOD, followed by CAT and POD, were either unchanged or at lower levels compared with the control of $100 \%$ peat. The exception to the above was the increased SOD and POD activity in broccoli at $10 \%$ of PW when compared to the control, and this was possibly due to the lowest AFP levels observed in 10\% PW growing media causing environmental stress to some part and/or species sensitivity to low AFP. Similarly, the use up to $30 \%$ of olive-stone waste in the potting growing media for ornamentals revealed similar antioxidant enzyme activity with the control, indicating absence of physiological stress [28]. In previous studies, ornamental plants grown in pots with PW-based media revealed oxidative stress with both damage indexes (MDA, $\mathrm{H}_{2} \mathrm{O}_{2}$ ) and enzymes activity increases [29].
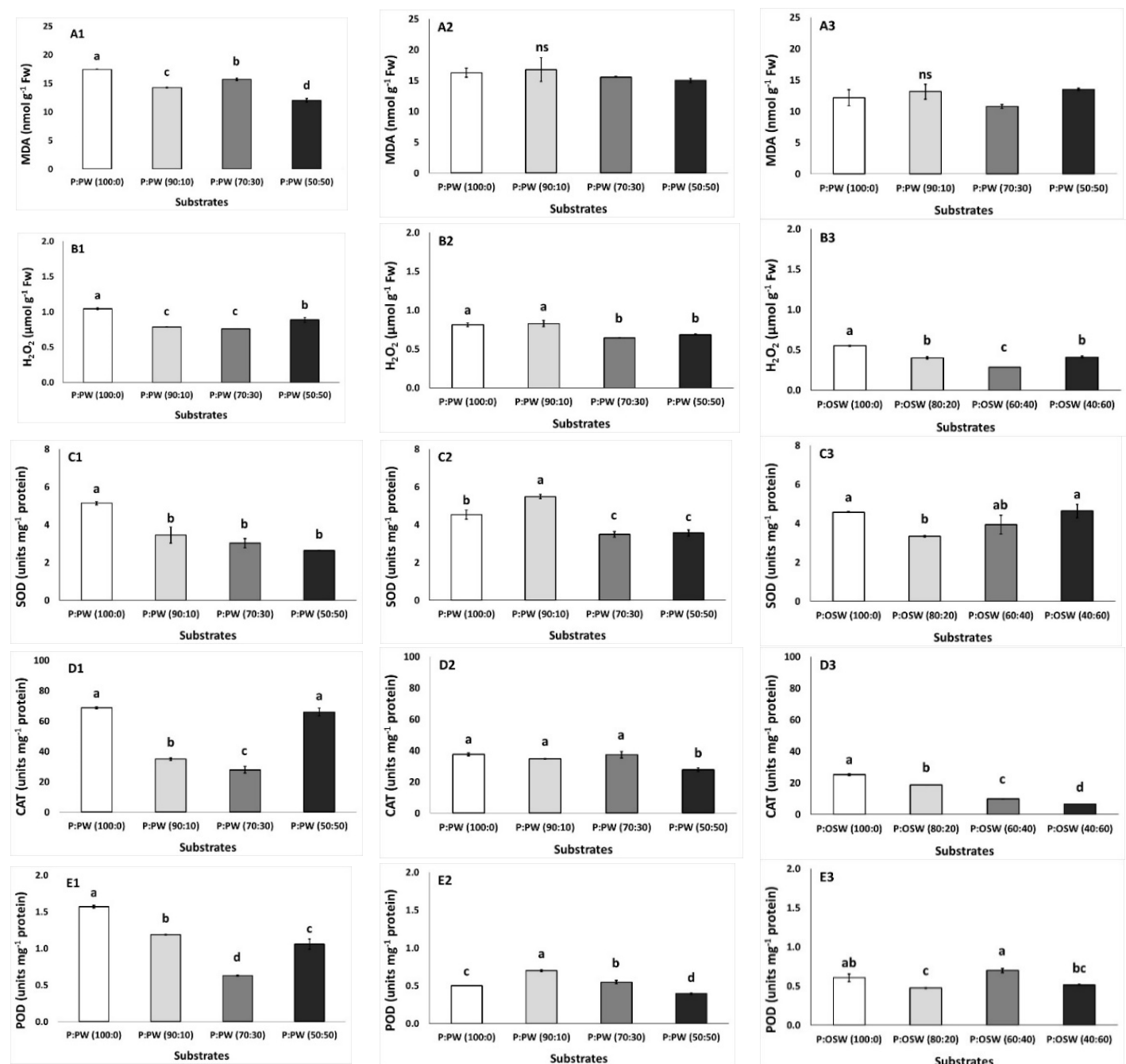

Figure 3. Effect of substrate media (peat-P, paper waste-PW) on damage index (lipid peroxidation-MDA, hydrogen peroxide- $\mathrm{H}_{2} \mathrm{O}_{2}$ ) and antioxidant enzymes (superoxide dismutase (SOD), catalase (CAT), and peroxidase activity (POD)) activities in cauliflower (A1-E1), broccoli (A2-E2), and cabbage (A3-E3) plants. Values are mean $\pm S E(n=3)$. Mean values followed by the same letter do not differ significantly at $p \geq 0.05$ according to Duncan's MRT. 
The impact of media properties on plant stress factors and antioxidants was studied. Phenol levels in cauliflowers increased with increasing organic matter levels, which was negatively correlated with PW rates in growing media ( $\mathrm{r}: 0.587, p<0.05)$ (Table S8). Phenol showed statistically significant negative correlations with media $\mathrm{Na}$ and $\mathrm{Cu}$ levels, which were linked with PW $(p<0.05)$. DPPH was the only plant parameter having strong positive correlations with increasing $\mathrm{PW}$ ratio and related parameters (bulk density, $\mathrm{EC}, \mathrm{pH}, \mathrm{C} / \mathrm{N}, \mathrm{Ca}, \mathrm{Na}, \mathrm{Fe}$, and $\mathrm{Cu}$ ) in growing media. FRAP, MDA, SOD, and POD were negatively influenced from increasing PW percentage $(r>-0.676, p<0.05)$ while these parameters had strong statistical correlations with media porosity, organic matter, and nitrogen. Media $\mathrm{Zn}$ levels, which was not linked with PW ratio, showed a positive impact on plant $\mathrm{H}_{2} \mathrm{O}_{2}$ and CAT levels $(p<0.01)$. Media Mn did not have any impact on plant stress factors and antioxidants.

Increasing rates of $\mathrm{PW}$ in growing media did not show any direct positive correlation with any of the plant parameters in broccoli. Instead, $\mathrm{H}_{2} \mathrm{O}_{2}, \mathrm{SOD}$, and CAT were negatively well correlated with PW, $\mathrm{pH}, \mathrm{Ca}$, and Fe $(p<0.05)$ (Table S9). However, DPPH had well correlations with media $\mathrm{pH}$ and $\mathrm{C} / \mathrm{N}$, which were mainly sourced from PW $(\mathrm{r}>0.600, p>0.05)$. Negative impacts of $\mathrm{Zn}$ and bulk density on POD were detected in broccoli.

PW and related media parameters such as bulk density, $\mathrm{pH}, \mathrm{Ca}, \mathrm{Na}$, and Fe were found correlated with cabbage DPPH (r: 0.564-0.797, $p<0.05$ ) (Table S10). CAT was statistically noticed as the only plant parameter that was negatively influenced by elevated media PW rates ( $\mathrm{r}:-0.972, p<0.001$ ). A negative influence of Mn on POD was also detected.

It was observed that the responses of studied plants' stress factors and antioxidant levels to changing growth medium PW ratio were not similar. DPPH was the only common plant parameter showing increase in all three plants with increasing PW rates. Cabbage could be evaluated as the most resistant plant to elevated PW rates with an only decrease seen in CAT, while decreases in broccoli $\mathrm{H}_{2} \mathrm{O}_{2}$, SOD, and CAT levels and cauliflower FRAP, MDA, SOD, and POD levels were observed.

\subsection{Principal Component Analysis}

The influence of PW containing growth media on plant properties was investigated for each of the studied plants. Principal component analysis was carried out individually for the datasets of plants' growth and physiology, minerals, antioxidants, and stress factors by concerning the PW ratios in growth media. The total variance explained by each of the PCA and the related component matrix are presented separately for cauliflower (Tables S11-S16), broccoli (Tables S17-S22), and cabbage (Tables S23-S28). A summary of the PCA analysis is presented with Table 5.

Table 5. Total variance accounted by principal component analysis performed and the variance of the principal component explaining the influence of PW in growth medium according to the datasets.

\begin{tabular}{|c|c|c|c|c|c|c|}
\hline \multirow{2}{*}{$\begin{array}{c}\text { Data Set } \\
\text { Plant }\end{array}$} & \multicolumn{2}{|c|}{$\begin{array}{l}\text { Plant Growth and } \\
\text { Physiology }\end{array}$} & \multicolumn{2}{|c|}{$\begin{array}{c}\text { Plant Stress Factors and } \\
\text { Antioxidants }\end{array}$} & \multicolumn{2}{|c|}{ Leaf Minerals } \\
\hline & $\begin{array}{c}\text { Total } \\
\text { Variance } \\
\text { Explained } \\
\text { by PCA,\% }\end{array}$ & $\begin{array}{c}\text { Variance of } \\
\text { PW } \\
\text { Containing } \\
\text { GM,\% }\end{array}$ & $\begin{array}{c}\text { Total } \\
\text { Variance } \\
\text { Explained } \\
\text { by PCA,\% }\end{array}$ & $\begin{array}{c}\text { Variance of } \\
\text { PW } \\
\text { Containing } \\
\text { GM,\% }\end{array}$ & $\begin{array}{c}\text { Total } \\
\text { Variance } \\
\text { Explained } \\
\text { by PCA,\% }\end{array}$ & $\begin{array}{c}\text { Variance of } \\
\text { PW } \\
\text { Containing } \\
\text { GM, } \%\end{array}$ \\
\hline Cauliflower & 83.81 & 52.89 & 81.34 & 52.00 & 97.36 & 48.95 \\
\hline Broccoli & 88.22 & 58.97 & 77.39 & 50.16 & 95.14 & 57.11 \\
\hline Cabbage & 81.71 & 62.41 & 89.53 & 44.10 & 94.91 & 37.56 \\
\hline
\end{tabular}

Plant Growth and Physiology: PCA explained the $83.8 \%$ of the total variance of the factors influencing the cauliflower growth and physiology (Table S11). Two principal components were extracted in the analysis. The first factor explains $52.9 \%$ of the total variance; high factor loading coefficients of PW (-0.947) and organic matter (0.911) emphasized that the properties of growing media was the major influence on the growth and physiological properties of cauliflower (Table S12). The variances 
explained by principal components were high and accounted for $88.2 \%$ of the total variances in the analysis of data on broccoli growth and physiology (Table S17). PC1 was highly loaded with PW $(-0.932)$ and SPAD (0.918) and explained $59 \%$ of the total variance, which was suggested as the growth medium properties (Table S18). PCA resulted with extraction of $81.7 \%$ of the total variance of the impacts on cabbage growth and physiology (Table S23). Similar to the cauliflower and broccoli plants, the first factor ( $\mathrm{PC} 1,62.4 \%$ ) represented the high impact of growth media properties on plant growth (Table S24). Considering the studied plants, it was seen that a major portion (58.09\% on average) of the possible influences on plant growth and physiology were sourced from growth medium properties. The influence of PW in growth media on plant growth and physiology in the decreasing order was found as: Cabbage $>$ Broccoli $>$ Cauliflower.

Plant Stress Factors and Antioxidants: PCA carried out for identification of the factors influencing cauliflower stress factors and antioxidants resulted in an extraction of $81.3 \%$ of the total variance (Table S13). Two principal components (PC) were extracted (Table S14). In PC1 (52.0\%), high factor loadings of SOD (0.988) and DPPH (-0.806) were present together with PW (-0.774) and organic matter (0.638). Therefore, PC1 was considered as the influence of growth medium properties. Principal component analysis accounted for $77.4 \%$ of the total variance of the possible influences on broccoli stress factors and antioxidants (Table S19). PW (-0.908) and $\mathrm{H}_{2} \mathrm{O}_{2}(0.911)$ were mainly loaded in PC1 $(50.2 \%)$, which represented the impact of PW containing growth medium (Table S20). For cabbage, three principal components were extracted by processing the data on plant stress factors and antioxidants; PCA accounted with $89.5 \%$ of the total variance (Table S25). PC1 (44.1\%) was found as directly linked with growth media properties. When the average values were taken into consideration, it was understood that $48.75 \%$ of the total variance of plant stress factor and antioxidants were affected by growth medium containing PW (Table S26). The impact of PW in growth media on plant stress factor and antioxidants in the decreasing order was found as: Cauliflower $>$ Broccoli $>$ Cabbage.

Leaf Minerals: $97 \%$ of the total variance of the factors influencing the cauliflower leaf mineral levels was explained by PCA (Table S15). Three PCs were extracted. The first principal component (PC1) explained $49.0 \%$ of the total variance and high factor loadings of PW (0.972), Ca (0.958), and Cu (0.949) were loaded in this factor (Table S16). Therefore, the main source of the minerals in cauliflower leaves can be proposed as PW. This finding also indicated that some minerals in $\mathrm{PW}(\mathrm{Ca}, \mathrm{Cu}, \mathrm{Mg})$ were in dissolvable forms. PCA explained $95.1 \%$ of the total variance of the data obtained for broccoli leaf minerals (Table S21). Three PCs were extracted. PC1 (57.1\%) was linked with PW and related minerals, which is why the impact of growth medium properties can be suggested (Table S22). The total variance explained by PCA was $94.9 \%$ in cabbage leaf minerals, where three PCs were extracted (Table S27). Since PC1 (37.6\%) was loaded with PW (0.858), this factor was evaluated as growth medium properties (Table S28). The average values showed that $47.87 \%$ of the total variance of studied plants' leaf minerals were sourced from growth medium that contains PW. The impact of PW in growth media on leaf mineral levels in the decreasing order was noticed as: Broccoli $>$ Cauliflower $>$ Cabbage.

The overall result obtained from the principal component analysis was that the growth medium containing PW had an important role in both the physical structure and chemical characteristics of the studied plants. To date, there is no a sole material to please all of the attractive features of peat for the successful peat substitution as component. However, several components have been shown to meet or even surpass peat for specific application and/or species [50], but a general application is not yet approved. In practice, most of the growing media are derived from sole or mixture of materials, raw material, or composted waste by-products $[23,27-29,32]$. The appropriate ratio of the different mixtures is necessary to be examined as commonly the ratio greater than $50 \%$ and occasionally up to $100 \%$ by volume, could presumably result in increases in EC and pH levels, in some cases toxic. This can be managed following controlled irrigation practices to speed the growing media salts leaching from the pot to the original levels $\left(\sim 1.0 \mathrm{mS} \mathrm{cm}^{-1}\right)$ [32]. Recently, the increase concern in waste management and recycling has yielded the expansion of organic materials and composts use as growing media for seedling and potting production presenting, simultaneously, an effective solution for waste disposal 
constrains. Paper sludge usually has 0.8 to $2.0 \mathrm{mS} \mathrm{cm}^{-1}$ being similar to our records, and has been effectively used as growing media [32]. To date, there has been rather narrow research outputs and few actual trials on the utilization of paper wastes, either composted or non-composted, as a growing media component. The obstacles of the low porosity and air-filled porosity observed with the PW use in this study can be improved with the substrate aeration increase, either by adding more inorganic material (i.e., perlite up to 30-35\%) or with the incorporation of materials with different particle size (i.e., sand, perlite, pumice, and vermiculate, among others).

\section{Conclusions}

The exploitation of organic wastes and the 3R (reduce, reuse, and recycle) tendency of wastes have become of great interest and attractive due to the possible use of waste derived from industrial sectors for mineral application and/or soil improvement in agriculture. Greener and sustainable agriculture is promoting the peat savings restoration, and alternative growing media are searched for use in nurseries. PW is an auspicious alternative, which reflected the scope of the present study, to partial peat replacement for Brassica seedling production. The addition of PW altered the physicochemical characteristics of the examined substrates, by raising bulk density and available minerals of the media and reducing the actual porosity. The PW-based media decreased the plant growth causing reduction in the plant height, number of leaves, and plant fresh weight for the cauliflower, cabbage, and broccoli. Even though PW reduced plant physiological properties (stomatal conductance, chlorophylls levels), the PW into the growing media changed the plant minerals accumulation, with increases of $\mathrm{N}, \mathrm{K}, \mathrm{Mg}$, and Ca levels. Furthermore, the PW increased the levels of phenols and antioxidants in cauliflower and cabbage but remained unchanged in broccoli, which is considered to be slightly more resistant. Despite the decreased growth and physiological parameters, PW did not cause major cellular damage to plant tissue as lipid peroxidation and the $\mathrm{H}_{2} \mathrm{O}_{2}$ production remained at lower or unchanged levels compared to the peat-grown plants. The current work implies that up to $10 \%$ of PW can replace peat for Brassica seedling production while the growing media itself required additional physicochemical properties improvements, mainly air-filled porosity. In addition, this also provides an incentive for efficient waste disposal, which naturally shows a cleaner approach towards sustainable environmental management.

Supplementary Materials: The following are available online at http://www.mdpi.com/2071-1050/12/15/5992/s1, Figure S1. Effect of substrate media (peat-P, paper waste-PW) on plant growth of cauliflower, broccoli and cabbage. Table S1. Intercorrelations of Media Properties. Table S2. The Correlations between the Growing Media Properties and Plant Growth and Physiology-Cauliflower. Table S3. The Correlations between the Growing Media Properties and Plant Growth and Physiology-Broccoli. Table S4. The Correlations between the Growing Media Properties and Plant Growth and Physiology-Cabbage. Table S5. The Correlations between the Growing Media properties and Plant Minerals-Cauliflower. Table S6. The Correlations between the Growing Media properties and Plant Minerals-Broccoli. Table S7. The Correlations between the Growing Media properties and Plant Minerals-Cabbage. Table S8. The Correlations between the Growing Media properties and Plant Antioxidants-Cauliflower. Table S9. The Correlations between the Growing Media properties and Plant Antioxidants-Broccoli. Table S10. The Correlations between the Growing Media properties and Plant Antioxidants-Cabbage. Table S11. Principal Component Analysis of Data Obtained for Cauliflower-Total Variance Explained for Plant Growth and Physiology. Table S12. Principal Component Analysis of Data Obtained for Cauliflower-Component matrix for plant growth and physiology. Table S13. Principal Component Analysis of Data Obtained for Cauliflower-Total Variance Explained for Antioxidants and Stress Factors. Table S14. Principal Component Analysis of Data Obtained for Cauliflower-Component matrix for plant stress factors and antioxidants. Table S15. Principal Component Analysis of Data Obtained for Cauliflower-Total Variance Explained for Plant Minerals. Table S16. Principal Component Analysis of Data Obtained for Cauliflower-Component matrix for leaf mineral levels. Table S17. Principal Component Analysis of Data Obtained for Broccoli-Total Variance Explained for Plant Growth and Physiology. Table S18. Principal Component Analysis of Data Obtained for Broccoli-Component matrix for plant growth and physiology. Table S19. Principal Component Analysis of Data Obtained for Broccoli-Total Variance Explained for Antioxidants and Stress Factors. Table S20. Principal Component Analysis of Data Obtained for Broccoli-Component matrix for plant stress factors and antioxidants. Table S21. Principal Component Analysis of Data Obtained for Broccoli-Total Variance Explained for Plant Minerals. Table S22. Principal Component Analysis of Data Obtained for Broccoli-Component matrix for leaf mineral levels. Table S23. Principal Component Analysis of Data Obtained for Cabbage-Total Variance Explained for Plant Growth and Physiology. Table S24. Principal Component Analysis of Data Obtained for Cabbage-Component matrix for plant growth and physiology. Table S25. Principal Component Analysis of 
Data Obtained for Cabbage-Total Variance Explained for Antioxidants and Stress Factors. Table S26. Principal Component Analysis of Data Obtained for Cabbage-Component matrix for plant stress factors and antioxidants. Table S27. Principal Component Analysis of Data Obtained for Cabbage-Total Variance Explained for Plant Minerals. Table S28. Principal Component Analysis of Data Obtained for Cabbage-Component matrix for leaf mineral levels.

Author Contributions: Conceptualization, A.C. and N.T.; methodology, A.C., G.A., K.M., and N.T.; software, A.C. and G.A.; validation, A.C., G.A., and N.T.; formal analysis, A.C., P.X., G.A., and N.T.; investigation, A.C., P.X., and N.T.; resources, N.T.; data curation, A.C., G.A., and N.T.; writing-original draft preparation, A.C., P.X., G.A., and N.T.; writing-review and editing, A.C., G.A., K.M., and N.T.; visualization, A.C., G.A, and K.M.; supervision, N.T.; project administration, N.T.; funding acquisition, N.T. All authors have read and agreed to the published version of the manuscript.

Funding: This work was funded by Cyprus University of Technology Open Access Author Fund.

Acknowledgments: The authors are thankful to the Cyprus University of Technology Open Access Author Fund.

Conflicts of Interest: The authors declare no conflict of interest.

\section{References}

1. Jaria, G.; Silva, C.P.; Ferreira, C.I.A.; Otero, M.; Calisto, V. Sludge from paper mill effluent treatment as raw material to produce carbon adsorbents: An alternative waste management strategy. J. Environ. Manag. 2017, 188, 203-211. [CrossRef]

2. Rashid, M.; Barry, D.; Goss, M. Paper mill biosolids application to agricultural lands: Benefits and environmental concerns with special reference to situation in Canada. Soil Env. 2006, 25, 85-98.

3. Oral, J.; Sikula, J.; Puchyr, R.; Hajny, Z.; Stehlik, P.; Bebar, L. Processing of waste from pulp and paper plant. J. Clean. Prod. 2005, 13, 509-515. [CrossRef]

4. Tucker, P.; Douglas, P. Composted Paper Mill Waste as a Peat Substitute; Newspaper Industry Environmental Technology Initiative; University of Paisley: Glasgow, UK, 2006.

5. Das, R.K.; Brar, S.K.; Verma, M. Potential use of pulp and paper solid waste for the bio-production of fumaric acid through submerged and solid state fermentation. J. Clean. Prod. 2016, 112, 4435-4444. [CrossRef]

6. Méndez, A.; Barriga, S.; Fidalgo, J.M.; Gascó, G. Adsorbent materials from paper industry waste materials and their use in $\mathrm{Cu}(\mathrm{II})$ removal from water. J. Hazard. Mater. 2009, 165, 736-743. [CrossRef] [PubMed]

7. de Azevedo, A.R.G.; Alexandre, J.; Marvila, M.T.; Xavier, G.; de, C.; Monteiro, S.N.; Pedroti, L.G. Technological and environmental comparative of the processing of primary sludge waste from paper industry for mortar. J. Clean. Prod. 2020, 249, 119336. [CrossRef]

8. Zhang, Q.; Khan, M.U.; Lin, X.; Yi, W.; Lei, H. Green-composites produced from waste residue in pulp and paper industry: A sustainable way to manage industrial wastes. J. Clean. Prod. 2020, 262, 121251. [CrossRef]

9. Joshi, G.; Naithani, S.; Varshney, V.K.; Bisht, S.S.; Rana, V. Potential use of waste paper for the synthesis of cyanoethyl cellulose: A cleaner production approach towards sustainable environment management. J. Clean. Prod. 2017, 142, 3759-3768. [CrossRef]

10. Kumar, P.R.; Jayaram, A.; Somashekar, R.K. Assessment of the performance of different compost models to manage urban household organic solid wastes. Clean Technol. Environ. Policy 2009, 11, 473-484. [CrossRef]

11. Ravindran, B.; Mnkeni, P.N.S. Bio-optimization of the carbon-to-nitrogen ratio for efficient vermicomposting of chicken manure and waste paper using Eisenia fetida. Environ. Sci. Pollut. Res. 2016, 23, 16965-16976. [CrossRef]

12. Yilmaz, M.; Gumuskaya, T. Recycling costs: A research in the waste paper industry. Eur. J. Acc. Aud. Fin. Res. 2015, 3, 58-68.

13. Caputo, A.C.; Pelagagge, P.M. Waste-to-energy plant for paper industry sludges disposal: Technical-economic study. J. Hazard. Mater. 2001, 81, 265-283. [CrossRef]

14. Abbasi, S.A.; Hussain, N.; Tauseef, S.M.; Abbasi, T. A novel FLippable Units Vermireactor Train System-FLUVTS - for rapidly vermicomposting paper waste to an organic fertilizer. J. Clean. Prod. 2018, 198, 917-930. [CrossRef]

15. Vieira, C.; Pinheiro, R.; Rodriguez, R.; Candido, V.; Monteiro, S. Clay bricks added with effluent sludge from paper industry. Technical, economical and environmental benefits. Appl. Clay Sci. 2016, 132-133, 753-759. [CrossRef] 
16. Bugbee, G. Growth of ornamental plants in container media amended with biosolids composts. Compost. Sci. Util. 2002, 10, 92-98. [CrossRef]

17. Landis, T.D.; Morgan, N. Growing Media Alternatives for Forest and Native Plant Nurseries. National Proceedings: Forest and Conservation Nursery Associations-2008; Rocky Mountain Research Station-P-58; US Department of Agricultur: Broomfield, CO, USA, 2009; pp. 26-31.

18. Holmes, S. Growing media developments in the UK. Acta Hortic. 2009, 819, 23-26. [CrossRef]

19. Kern, J.; Tammeorg, P.; Shanskiy, M.; Sakrabani, R.; Knicker, H.; Kammann, C.; Tuhkanen, E.M.; Smidt, G.; Prasad, M.; Tiilikkala, K.; et al. Synergistic use of peat and charred material in growing media-an option to reduce the pressure on peatlands? J. Environ. Eng. Landsc. Manag. 2017, 25, 160-174. [CrossRef]

20. Ceglie, F.G.; Bustamante, M.A.; Amara, M.B.; Tittarelli, F. The challenge of peat substitution in organic seedling production: Optimization of growing media formulation through mixture design and response surface analysis. PLoS ONE 2015, 10, e0128600. [CrossRef]

21. Abad, M.; Noguera, P.; Burés, S. National inventory of organic wastes for use as growing media for ornamental potted plant production: Case study in Spain. Bioresour. Technol. 2001, 77, 197-200. [CrossRef]

22. Chrysargyris, A.; Antoniou, O.; Athinodorou, F.; Vassiliou, R.; Papadaki, A.; Tzortzakis, N. Deployment of olive-stone waste as a substitute growing medium component for Brassica seedling production in nurseries. Environ. Sci. Pollut. Res. 2019. [CrossRef]

23. Papamichalaki, M.; Papadaki, A.; Tzortzakis, N. Substitution of peat with municipal solid waste compost in watermelon seedling production combined with fertigation. Chil. J. Agric. Res. 2014, 74, 452-459. [CrossRef]

24. Jayasinghe, G.Y.; Tokashiki, Y.; Kitou, M.; Kinjo, K. Oil palm waste and synthetic zeolite: An alternative soil-less growth substrate for lettuce production as a waste management practice. Waste Manag. Res. 2008, 26, 559-565. [CrossRef]

25. Fascella, G. Growing substrates alternative to peat for ornamental plants. In Soilless Culture-Use of Substrates for the Production of Quality Horticultural Crops; Asaduzzaman, M., Ed.; InTech: Rijeka, Croatia, 2015; ISBN 978-953-51-1739-1.

26. Kelepesi, S.; Tzortzakis, N.G. Olive mill wastesA growing medium component for seedling and crop production of lettuce and chicory. Int. J. Veg. Sci. 2009, 15, 325-339. [CrossRef]

27. Prasad, M.; Tzortzakis, N.; McDaniel, N. Chemical characterization of biochar and assessment of the nutrient dynamics by means of preliminary plant growth tests. J. Environ. Manag. 2018, 216, 89-95. [CrossRef]

28. Chrysargyris, A.; Antoniou, O.; Tzionis, A.; Prasad, M.; Tzortzakis, N. Alternative soilless media using olive-mill and paper waste for growing ornamental plants. Environ. Sci. Pollut. Res. 2018, 25, 35915-35927. [CrossRef] [PubMed]

29. Chrysargyris, A.; Stavrinides, M.; Moustakas, K.; Tzortzakis, N. Utilization of paper waste as growing media for potted ornamental plants. Clean Technol. Environ. Policy 2019, 21, 1937-1948. [CrossRef]

30. WRAP Research Analysis of the Market Potential for Lower Grade Composted Materials in the UK; WRAP: Banbury, UK, 2002.

31. Tzortzakis, N.G.; Economakis, C.D. Shredded maize stems as an alternative substrate medium: Effect on growth, flowering and yield of tomato in soilless culture. J. Veg. Sci. 2005, 11, 57-70. [CrossRef]

32. Chong, C. Experiences with wastes and composts in nursery substrates. Horttechnology 2005, 15, 739-747. [CrossRef]

33. Wuana, R.A.; Okieimen, F.E. Heavy Metals in Contaminated Soils: A Review of Sources, Chemistry, Risks and Best Available Strategies for Remediation. ISRN Ecol. 2011, 2011, 1-20. [CrossRef]

34. European Committee for Standardization. European standard EN 13041. Soil Improvers and Growing Media-Determination of Physical Properties-Dry Bulk Density, Air Volume, Water Volume, Shrinkage Value and Total Pore Space; European Committee for Standardization: Brussels, Belgium, 1999.

35. Chrysargyris, A.; Xylia, P.; Botsaris, G.; Tzortzakis, N. Antioxidant and antibacterial activities, mineral and essential oil composition of spearmint (Mentha spicata L.) affected by the potassium levels. Ind. Crops Prod. 2017, 103, 202-212. [CrossRef]

36. Chrysargyris, A.; Papakyriakou, E.; Petropoulos, S.A.; Tzortzakis, N. The combined and single effect of salinity and copper stress on growth and quality of Mentha spicata plants. J. Hazard. Mater. 2019, 368, 584-593. [CrossRef] [PubMed]

37. Tzortzakis, N.G.; Tzanakaki, K.; Economakis, C.D.C.D. Effect of origanum oil and vinegar on the maintenance of postharvest quality of tomato. Food Nutr. Sci. 2011, 2, 974-982. [CrossRef] 
38. Loreto, F.; Velikova, V. Isoprene produced by leaves protects the photosynthetic apparatus against ozone damage, quenches ozone products, and reduces lipid peroxidation of cellular membranes. Plant Physiol. 2001, 127, 1781-1787. [CrossRef] [PubMed]

39. De Azevedo Neto, A.D.; Prisco, J.T.; Enéas-Filho, J.; De Abreu, C.E.B.; Gomes-Filho, E. Effect of salt stress on antioxidative enzymes and lipid peroxidation in leaves and roots of salt-tolerant and salt-sensitive maize genotypes. Environ. Exp. Bot. 2006, 56, 87-94. [CrossRef]

40. Ribeiro, H.M.; Vasconcelos, E.; Cabral, F.; Ribeiro, D. Fertilization of Pinus pinea L. seedlings with a sewage sludge-based compost. Waste Manag. Res. 2009, 27, 112-118. [CrossRef]

41. Ouzounidou, G.; Asfi, M.; Sotirakis, N.; Papadopoulou, P.; Gaitis, F. Olive mill wastewater triggered changes in physiology and nutritional quality of tomato (Lycopersicon esculentum Mill.) depending on growth substrate. J. Hazard. Mater. 2008, 158, 523-530. [CrossRef]

42. Mohammadi Torkashvand, A.; Haghighat, N.; Shadparvar, V. Effect of paper mill lime sludge as an acid soil amendment. Sci. Res. Essays 2010, 5, 1302-1306.

43. He, J.; Lange, C.R.; Dougherty, M. Laboratory study using paper mill lime mud for agronomic benefit. Process Saf. Environ. Prot. 2009, 87, 401-405. [CrossRef]

44. Havlin, J.; Beaton, J.; Tisdale, S.; Werner, L. Soil Fertility and Fertilizers. An Introduction to Nutrient Management; Prentice Hall: Upper saddle River, NJ, USA, 2005.

45. Mertoglu-Elmas, G. The effect of colorants on the content of heavy metals in recycled corrugated board papers. BioResources 2017, 12, 2690-2698. [CrossRef]

46. Perez-Murcia, M.D.; Moral, R.; Moreno-Caselles, J.; Perez-Espinosa, A.; Paredes, C. Use of composted sewage sludge in growth media for broccoli. Bioresour. Technol. 2006, 97, 123-130. [CrossRef]

47. Kiarostami, K.; Mohseni, R.; Saboora, A. Biochemical changes of Rosmarinus officinalis under salt stress. J. Stress Physiol. Biochem. 2010, 6, 114-122.

48. Hara, T.; Sonoda, Y. The role of macronutrients for cabbage-head formation: I. contribution to cabbage-head formation of nitrogen, phosphorus, or potassium supplied at different growth stages. Soil Sci. Plant Nutr. 1979, 25, 113-120. [CrossRef]

49. Tarchoune, I.; Sgherri, C.; Izzo, R.; Lachaal, M.; Ouerghi, Z.; Navari-Izzo, F. Antioxidative responses of Ocimum basilicum to sodium chloride or sodium sulphate salinization. Plant Physiol. Biochem. 2010, 48, 772-777. [CrossRef] [PubMed]

50. Morrish, R.; Hofstede, H. Alternatives to Peat: A Manual; Murdoch University: Perth, Australia, 2000. 